\title{
The fate of fixed nitrogen in marine sediments with low organic loading: an in situ study
}

\author{
Stefano Bonaglia ${ }^{1, a}$, Astrid Hylén ${ }^{2}$, Jayne E. Rattray ${ }^{1}$, Mikhail Y. Kononets ${ }^{2}$, Nils Ekeroth ${ }^{2,3}$, Per Roos $^{4}$, \\ Bo Thamdrup ${ }^{5}$, Volker Brüchert ${ }^{1}$, and Per O. J. Hall ${ }^{2}$ \\ ${ }^{1}$ Department of Geological Sciences and Bolin Centre for Climate Research, Stockholm University, Stockholm, Sweden \\ ${ }^{2}$ Department of Marine Sciences, University of Gothenburg, Gothenburg, Sweden \\ ${ }^{3}$ Calluna AB, Nacka, Sweden \\ ${ }^{4}$ Center for Nuclear Technologies, Technical University of Denmark, Roskilde, Denmark \\ ${ }^{5}$ Department of Biology and Nordic Center for Earth Evolution, University of Southern Denmark, Odense M, Denmark \\ a current address: Department of Geology, Lund University, Lund, Sweden
}

Correspondence to: Stefano Bonaglia (stefano.bonaglia@gmail.com)

Received: 18 August 2016 - Published in Biogeosciences Discuss.: 19 August 2016

Revised: 21 December 2016 - Accepted: 27 December 2016 - Published: 19 January 2017

\begin{abstract}
Over the last decades, the impact of human activities on the global nitrogen $(\mathrm{N})$ cycle has drastically increased. Consequently, benthic $\mathrm{N}$ cycling has mainly been studied in anthropogenically impacted estuaries and coasts, while in oligotrophic systems its understanding is still scarce. Here we report on benthic solute fluxes and on rates of denitrification, anammox, and dissimilatory nitrate reduction to ammonium (DNRA) studied by in situ incubations with benthic chamber landers during two cruises to the Gulf of Bothnia (GOB), a cold, oligotrophic basin located in the northern part of the Baltic Sea. Rates of $\mathrm{N}$ burial were also inferred to investigate the fate of fixed $\mathrm{N}$ in these sediments. Most of the total dissolved fixed nitrogen (TDN) diffusing to the water column was composed of organic N. Average rates of dinitrogen $\left(\mathrm{N}_{2}\right)$ production by denitrification and anammox (range: $53-360 \mu \mathrm{mol} \mathrm{N} \mathrm{m}^{-2} \mathrm{day}^{-1}$ ) were comparable to those from Arctic and subarctic sediments worldwide (range: $34-344 \mu \mathrm{mol} \mathrm{N} \mathrm{m}{ }^{-2} \mathrm{day}^{-1}$ ). Anammox accounted for 18 $26 \%$ of the total $\mathrm{N}_{2}$ production. Absence of free hydrogen sulfide and low concentrations of dissolved iron in sediment pore water suggested that denitrification and DNRA were driven by organic matter oxidation rather than chemolithotrophy. DNRA was as important as denitrification at a shallow, coastal station situated in the northern Bothnian Bay. At this pristine and fully oxygenated site, ammonium regeneration through DNRA contributed more than one-third to the TDN efflux and accounted, on average, for $45 \%$ of to-
\end{abstract}

tal nitrate reduction. At the offshore stations, the proportion of DNRA in relation to denitrification was lower (0-16\% of total nitrate reduction). Median value and range of benthic DNRA rates from the GOB were comparable to those from the southern and central eutrophic Baltic Sea and other temperate estuaries and coasts in Europe. Therefore, our results contrast with the view that DNRA is negligible in cold and well-oxygenated sediments with low organic carbon loading. However, the mechanisms behind the variability in DNRA rates between our sites were not resolved. The GOB sediments were a major source $\left(237 \mathrm{kt} \mathrm{yr}^{-1}\right.$, which corresponds to $184 \%$ of the external $\mathrm{N}$ load) of fixed $\mathrm{N}$ to the water column through recycling mechanisms. To our knowledge, our study is the first to document the simultaneous contribution of denitrification, DNRA, anammox, and TDN recycling combined with in situ measurements.

\section{Introduction}

Excess of fixed nitrogen $(\mathrm{N})$ accumulating in aquatic ecosystems due to planktonic dinitrogen $\left(\mathrm{N}_{2}\right)$ fixation, discharge of wastewater, and runoff of fertilizers constitutes one of the greatest eutrophication issues in coastal waters (Howarth and Marino, 2006), ultimately leading to water column anoxia and biodiversity loss (Vaquer-Sunyer and Duarte, 2008). Coastal, estuarine, and shelf sediments contribute $\sim 45 \%$ of 
the global $\mathrm{N}$ loss due to the two anaerobic, microbial processes denitrification and anammox (Seitzinger et al., 2006). Denitrification is the stepwise reduction of nitrate to nitrous oxide and $\mathrm{N}_{2}$, while anammox produces $\mathrm{N}_{2}$ through ammonium oxidation coupled to nitrite reduction. These two processes help in counteracting eutrophication by permanent removal of fixed $\mathrm{N}$ from the system. A third $\mathrm{N}$ reducing process, dissimilatory nitrate reduction to ammonium (DNRA), leads to recycling and preservation of fixed $\mathrm{N}$ in the system and can ultimately increase the occurrence of algal blooms and exacerbate eutrophication if stimulated at the expense of the $\mathrm{N}_{2}$-producing pathways (An and Gardner, 2002; Bonaglia et al., 2014a).

In sediments with high sulfide concentrations, DNRA is generally of major importance (Bonaglia et al., 2014a; Christensen et al., 2000; De Brabandere et al., 2015). This is likely because sulfide is used as the electron donor in the nitrate reduction process which is carried out by large sulfur bacteria that proliferate in these conditions (Jørgensen and Nelson, 2004). DNRA dominates nitrate reduction also in sediments with high organic carbon (C) loading in tropical (Dong et al., 2011) and subtropical (An and Gardner, 2002) estuarine sediments, where high $\mathrm{C}: \mathrm{N}$ ratios would favor this process over denitrification and anammox (Burgin and Hamilton, 2007; Kraft et al., 2014). It has recently been proposed that reduced iron can serve as an alternative electron donor for DNRA in estuarine sediments (Robertson et al., 2016). The few experimental studies conducted in permanently cold $\left(<10^{\circ} \mathrm{C}\right)$, oligotrophic marine systems have suggested that the role of DNRA is negligible, while denitrification and anammox have been considered the main nitrate/nitrite (as $\mathrm{NO}_{3}^{-}+\mathrm{NO}_{2}^{-}=\mathrm{NO}_{x}^{-}$) reduction processes (NRPs) (Crowe et al., 2012; Gihring et al., 2010). However, bacterial assimilation has also been found to be an important nitrate removal pathway in cold, low-organic Arctic sediments (Blackburn et al., 1996). In marine systems, anammox is, in relation to denitrification, generally more important in deep environments particularly in manganese (Mn)-rich sediments, where the lower contribution of denitrification may be due to competition with Mn reduction for organic substrates (Engström et al., 2005; Trimmer et al., 2013). Yet factors responsible for the relative partitioning between the three NRPs in loworganic sediments are still obscure.

The southern and central Baltic Sea are among the most eutrophic marine areas in the world, due to large inputs of nutrients, extended thermohaline stratification, and limited water circulation (Elmgren, 2001). However, the northern part of the Baltic Sea - the Gulf of Bothnia (GOB) - is still relatively unaffected by anthropogenic nutrient loading because of low population density and extensive forest coverage in its catchment area (Pettersson et al., 1997), which prevent the risk of dense planktonic blooms similarly to the Arctic coastal zones (Billen et al., 2011). Planktonic primary production in the waters of the GOB is considered to be mainly limited by phosphorus $(\mathrm{P})$, while dissolved inorganic $\mathrm{N}$ is generally abundant (Rolff and Elfwing, 2015; Tamminen and Andersen, 2007). In contrast to the southern Baltic, the GOB water column is well oxygenated, suggesting that anaerobic NRPs occur exclusively in the sediments. To our knowledge, only two studies report rates of benthic denitrification in the GOB, but they do not report anammox and DNRA activity (Stockenberg and Johnstone, 1997; Tuominen et al., 1998).

This study targeted rates of NRPs in sediments of the GOB by in situ benthic lander incubations supported by additional on-deck incubations, as the main aim was to better understand processes of the $\mathrm{N}$ cycling in this relatively unexplored Baltic Sea basin. The oligotrophic, cold waters of the GOB make this basin an ideal environment in which to study the relative importance of individual NRPs under pristine conditions. Based on reported chemical data, we hypothesized low benthic $\mathrm{N}$ cycling rates dominated by denitrification and anammox, with the latter process prevailing at high Mn concentrations. Pore-water chemistry, anammox biomarkers, and $\mathrm{C}: \mathrm{N}$ ratios were also characterized as they may help explain variations in rates of $\mathrm{N}$ cycling processes. To investigate the fate of fixed $\mathrm{N}, \mathrm{N}$ burial and efflux from the sediment were also quantified.

\section{Methods}

\subsection{Study area and sampling}

The GOB, which by area and volume represents the second largest basin of the Baltic Sea after the Baltic proper, is the northernmost Baltic basin and is further divided into the Bothnian Bay (BB) and the Bothnian Sea (BS) (Fig. 1). The areas of the BB and BS cover 36260 and $64886 \mathrm{~km}^{2}$, with mean depths of 41 and $66 \mathrm{~m}$, respectively (Leppäranta and Myrberg, 2009). Both basins are normally covered by ice during winter for on average 120 and 60 days in the BB and BS, respectively (Håkansson et al., 1996). Bottomwater salinity decreases from 6 in the southern section of the BS to 2 in the northern section of the BB. Due to sills and archipelago areas in the south of the BS, the GOB remains largely isolated from the density-stratified waters of the Baltic proper. As such, and because of the low productivity and weak stratification of its water masses, the GOB is generally well oxygenated throughout the year, and hypoxia has not significantly affected the GOB in the last centuries (Savchuk, 2013). The entire BB and the offshore waters of the BS are considered oligotrophic and P-limited in their current state (Billen et al., 2011; Tamminen and Andersen, 2007).

The four sampling stations (RA2, GOB1, GOB2, and GOB3) are located along a bottom-water salinity gradient, on a north-south transect across the GOB (Fig. 1). RA2 is a shallow coastal station situated just outside the mouth of the Råne River, while GOB1, GOB2, and GOB3 are offshore 
Table 1. Main site parameters obtained at the investigated sites. SAR is the sediment accumulation rate and, OPD is the average oxygen penetration depth.

\begin{tabular}{|c|c|c|c|c|c|c|c|c|}
\hline Station & $\begin{array}{l}\text { Sampling } \\
\text { season }\end{array}$ & Coordinates & $\begin{array}{r}\text { Depth } \\
(\mathrm{m})\end{array}$ & $\begin{array}{r}\text { Temperature } \\
\left({ }^{\circ} \mathrm{C}\right)\end{array}$ & Salinity & $\begin{array}{r}\text { SAR } \\
\left(\mathrm{g} \mathrm{cm}^{-2} \mathrm{yr}^{-1}\right)\end{array}$ & $\begin{array}{r}\text { Burial rate } \\
\left(\mathrm{mmol} \mathrm{N} \mathrm{m}^{-2} \text { day }^{-1}\right)\end{array}$ & $\begin{array}{l}\text { OPD } \\
(\mathrm{cm})\end{array}$ \\
\hline GOB1 & $\begin{array}{l}\text { June } 2013 \\
\text { July } 2014\end{array}$ & $23^{\circ} 23.7^{\prime} \mathrm{E}, 65^{\circ} 11.5^{\prime} \mathrm{N}$ & 86 & $\begin{array}{l}2.6 \\
1.9\end{array}$ & $\begin{array}{l}3.5 \\
3.4\end{array}$ & 0.032 & 0.098 & $\begin{array}{l}1.3 \\
1.1\end{array}$ \\
\hline GOB2 & $\begin{array}{l}\text { June } 2013 \\
\text { July } 2014\end{array}$ & $21^{\circ} 59.5^{\prime} \mathrm{E}, 64^{\circ} 11.6^{\prime} \mathrm{N}$ & 111 & $\begin{array}{l}1.4 \\
4.9\end{array}$ & $\begin{array}{l}4.0 \\
4.1\end{array}$ & 0.031 & 0.132 & $\begin{array}{l}1.9 \\
1.3\end{array}$ \\
\hline GOB3 & $\begin{array}{l}\text { June } 2013 \\
\text { July } 2014\end{array}$ & $18^{\circ} 33.2^{\prime} \mathrm{E}, 62^{\circ} 07.1^{\prime} \mathrm{N}$ & 91 & $\begin{array}{l}2.6 \\
3.2\end{array}$ & $\begin{array}{l}6.0 \\
6.2\end{array}$ & 0.022 & 0.124 & $\begin{array}{r}1.6 \\
0.80\end{array}$ \\
\hline RA2 & July 2014 & $22^{\circ} 26.8^{\prime} \mathrm{E}, 65^{\circ} 43.8^{\prime} \mathrm{N}$ & 12.5 & 8.4 & 2.6 & 0.029 & 0.155 & 0.24 \\
\hline
\end{tabular}

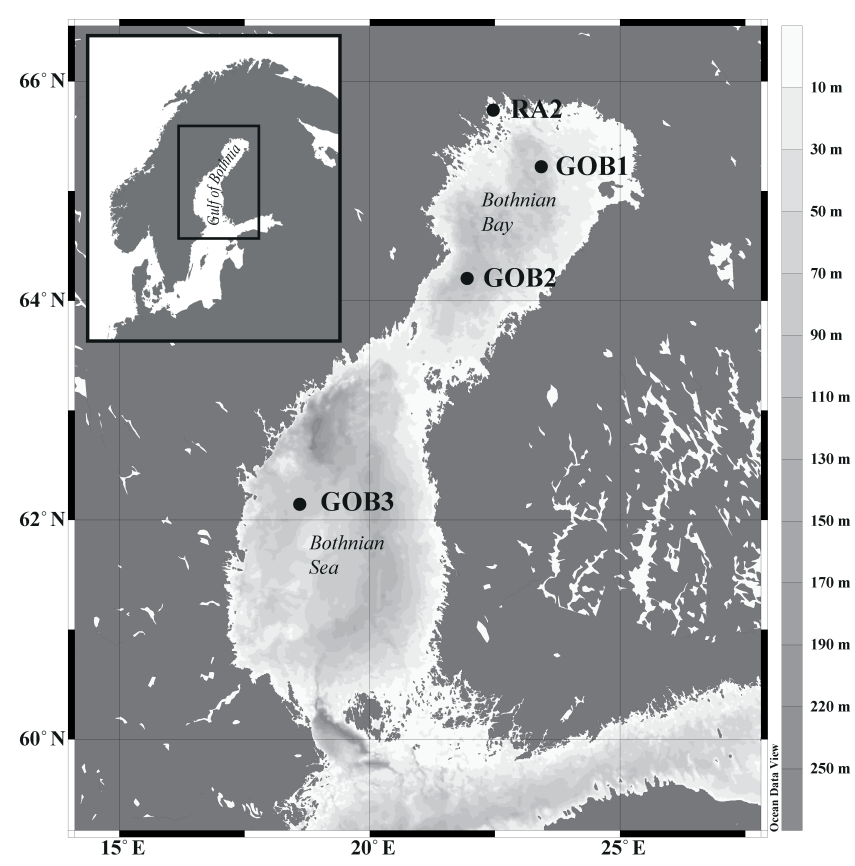

Figure 1. Location of the four sampling stations in the Gulf of Bothnia and bathymetry of its two sub-basins, the Bothnian Bay and the Bothnian Sea.

stations. RA2, GOB1, and GOB2 are in the $\mathrm{BB}$, while GOB3 is in the BS.

The stations were visited during two research expeditions, in June 2013 and in July 2014, with the only exception of station RA2, which was visited only during the second expedition (Table 1). In both years, in situ benthic chamber incubations were performed and sediment samples were collected for determination of various parameters. In 2014, we also performed on-deck incubations of sediment cores and anoxic slurries.

\subsection{Sediment properties}

For analysis of sediment physicochemical properties and pore water, seafloors were sampled by means of a modified box corer $(28 \times 28 \mathrm{~cm}$ internal diameter) (Blomqvist et al., $2015)$ and by a Gemini corer ( $9 \mathrm{~cm}$ internal diameter). Both samplers provided nearly undisturbed sediment surfaces.

At each station, one Gemini core was sliced at intervals of $0.5 \mathrm{~cm}$ down to $2 \mathrm{~cm}$ depth; at intervals of $1 \mathrm{~cm}$ from 2 to $6 \mathrm{~cm}$ depth; and at intervals of $2 \mathrm{~cm}$ from 6 to $20 \mathrm{~cm}$ depth. Each sediment slice was split; one half was frozen for organic geochemistry parameters, and the other refrigerated for later determination of water content and sediment accumulation rate (see below for analysis details). A second Gemini core was sliced at the same intervals to obtain pore-water nutrient profiles. The sediment slices were centrifuged at $670 \mathrm{~g}$ (2500-3000 rpm) for $15 \mathrm{~min}$, and the supernatant was immediately filtered using $0.45 \mu \mathrm{m}$ polyethersulfone (PES) filters and then stored dark and refrigerated until analysis. In 2013, $\mathrm{NH}_{4}^{+}$and the sum of $\mathrm{NO}_{2}^{-}+\mathrm{NO}_{3}^{-}\left(\mathrm{NO}_{x}^{-}\right)$were determined, while in 2014 the three dissolved inorganic nitrogen (DIN) species $\left(\mathrm{NH}_{4}^{+}, \mathrm{NO}_{3}^{-}\right.$, and $\left.\mathrm{NO}_{2}^{-}\right)$and total dissolved nitrogen (TDN) were analyzed (see below for details).

Two small plastic liners ( $4.6 \mathrm{~cm}$ internal diameter) were inserted into the box core sample and subsampled for on-deck microelectrode profiling of dissolved oxygen and sulfide concentrations. At least three to five microprofiles were measured in each of the two sediment cores using a Clark-type oxygen microsensor (OX-50, Unisense) and a hydrogen sulfide microsensor $\left(\mathrm{H}_{2} \mathrm{~S}-50\right.$, Unisense) mounted onto a doubleheaded motorized micromanipulator (MM33-2, Unisense), using a vertical resolution of $100 \mu \mathrm{m}$. Sulfide microprofiles were carried out down to $5 \mathrm{~cm}$ depth, while the $\mathrm{O}_{2}$ microprofiles were stopped immediately below the depth where $\mathrm{O}_{2}$ was exhausted. An overlying water column of $4 \mathrm{~cm}$ was left in the sediment core and circulated by a gentle flow of air towards the water surface from an angle of $\sim 45^{\circ}$ in order to obtain a stable diffusive boundary layer during measurements. Before measurements, OX-50 was calibrated using 
a two-point calibration procedure, while $\mathrm{H}_{2} \mathrm{~S}-50$ was calibrated daily in fresh anoxic $\mathrm{Na}_{2} \mathrm{~S}$ solutions according to the manufacturer's recommendation.

\subsection{In situ benthic chamber incubations}

The two Gothenburg benthic landers (big and small landers) were deployed at each station to measure benthic solute fluxes and $\mathrm{N}$ cycling process rates (Brunnegård et al., 2004; De Brabandere et al., 2015; Ståhl et al., 2004). The big and small landers are equipped with four and two box-shaped $(20 \mathrm{~cm} \times 20 \mathrm{~cm})$ incubation chamber modules, respectively. The landers' chambers enclosed sediment together with the overlying water (range: 8-12 L water), which was constantly stirred by a horizontal paddle wheel positioned centrally in each chamber (Tengberg et al., 2004). The chambers' lids were closed $2.5-3 \mathrm{~h}$ after the benthic lander was deployed on the sediments to assure proper ventilation before incubation started. Physicochemical conditions inside each chamber, as well as in the ambient bottom water just outside chambers, were monitored with an oxygen optode (3830 or 3835 , Aanderaa) and a salinity sensor (3919A, Aanderaa). Both optodes and conductivity sensors had temperature output. Each chamber was equipped with ten $60 \mathrm{~mL}$ syringes for solution injection and water sampling. Three of the six chambers were incubated for $\mathrm{O}_{2}$ and TDN flux determination (Ståhl et al., 2004). In these chambers, $10 \mathrm{~min}$ after the lid closed, the first syringe injected $60 \mathrm{~mL}$ distilled water, corresponding to $0.5-$ $1 \%$ of the chamber volume. Chamber volumes were calculated from the resulting decrease in salinity. Nine water samples were collected by syringe withdrawal at regular intervals during an incubation period of 29.5-33 h after the lid closed. After recovery of the landers, the syringe samples were filtered $(0.45 \mu \mathrm{m}, \mathrm{PES})$ and stored refrigerated until analysis for TDN concentrations immediately after each cruise.

The rest of the chambers were used for incubation with ${ }^{15} \mathrm{NO}_{3}^{-}$tracer for determination of denitrification and DNRA rates following the protocol by De Brabandere et al. (2015), with minor modification. In each of these chambers, $10 \mathrm{~min}$ after the lid closed a syringe withdrew a first water sample for nutrient analysis. Ten minutes later, $60 \mathrm{~mL}$ of a $12 \mathrm{mM}{ }^{15} \mathrm{NO}_{3}^{-}$solution (prepared by dissolving $\mathrm{Na}^{15} \mathrm{NO}_{3}$ 99.4 atom \% (Sigma-Aldrich) in distilled water) was injected by the second syringe to reach a final ${ }^{15} \mathrm{NO}_{3}^{-}$concentration of $\sim 70 \mu \mathrm{M}$ in the chamber. After another $10 \mathrm{~min}$ the third syringe withdrew a second water sample for nutrient analysis, from which ${ }^{15} \mathrm{NO}_{3}^{-}$amendment could be calculated. Seven water samples were collected by syringe withdrawal at regular intervals during an incubation period of 29-32.5 h after the initial operations were concluded. After recovery of the landers, the seven syringe samples from each of the ${ }^{15} \mathrm{NO}_{3}^{-}$-amended chambers were sampled first by filling a series of $12 \mathrm{~mL}$ Exetainers (Labco) to which $100 \mu \mathrm{L}$ of a $37 \%$ formaldehyde solution was added to stop biological activity. The Exetainers were stored upside down in a fridge for later analysis of the isotopic composition of $\mathrm{N}_{2}$. From the same syringe samples a second aliquot was filtered (PES, $0.45 \mu \mathrm{m}$ ) and split into two plastic vials, one for analysis of DIN and one for ${ }^{15} \mathrm{NH}_{4}^{+}$analysis. The nutrient vials were stored dark and refrigerated until analysis immediately after each cruise, while the ${ }^{15} \mathrm{NH}_{4}^{+}$vials were immediately frozen upright.

\subsection{Sediment core incubations}

In 2014, two sediment box core casts were sampled by inserting 15 plastic liners $(4.6 \mathrm{~cm}$ internal diameter, $30 \mathrm{~cm}$ length) and collecting half sediment and half water for sediment core incubations with the addition of ${ }^{15} \mathrm{NO}_{3}^{-}$to determine rates of denitrification and DNRA (De Brabandere et al., 2015; Nielsen, 1992). These incubations were used to determine the relative accumulation of ${ }^{15} \mathrm{~N}_{2}$ and ${ }^{15} \mathrm{NH}_{4}^{+}$in the sediment and the overlying water, respectively, in order to correct rates from benthic chamber incubations, as this procedure does not take into account the ${ }^{15} \mathrm{~N}_{2}$ and ${ }^{15} \mathrm{NH}_{4}^{+}$fractions trapped in the sediment (Nielsen, 1992). Since large chambers better capture the spatial heterogeneity of the sediment (Glud and Blackburn, 2002), we use the chamber-based rates as the best estimates of activity in situ.

The sediment cores were transferred into a $25 \mathrm{~L}$ incubation tank that was previously filled with ambient bottom water, situated in a temperature-controlled room kept at bottomwater temperature (Table 1). The cores were left uncapped for $6 \mathrm{~h}$, during which the water phase of each core was stirred with a magnetic bar driven by an external magnet at $60 \mathrm{rpm}$. Subsequently, $5 \mathrm{~mL}$ of a $200 \mathrm{mM}^{15} \mathrm{NO}_{3}^{-}$solution (prepared by dissolving $\mathrm{Na}^{15} \mathrm{NO}_{3} 99.4$ atom \% (Sigma-Aldrich) in distilled water) was added to the water tank in order to reach a ${ }^{15} \mathrm{NO}_{3}^{-}$concentration of $\sim 70 \mu \mathrm{M}$. Before and after this addition of ${ }^{15} \mathrm{NO}_{3}^{-}$solution, triplicate water samples were collected from the tank, filtered (PES, $0.45 \mu \mathrm{m}$ ), and stored dark and refrigerated for later $\mathrm{NO}_{3}^{-}$analysis to calculate the final ${ }^{15} \mathrm{NO}_{3}^{-}$amendment. The incubation started after a lag time of up to $14 \mathrm{~h}$, which was necessary to homogeneously mix the added nitrate with the endogenous nitrate and to establish a linear production of ${ }^{15} \mathrm{~N}_{2}$ within the sediment as inferred from the oxygen penetration depth. At the beginning of the incubation the cores were capped with rubber stoppers so that no air bubbles formed, and the water was mixed by externally driven magnetic bars. Triplicate cores were sampled at regular intervals during the incubation, which lasted $12 \mathrm{~h}$ at RA2 and $22 \mathrm{~h}$ at GOB1, GOB2, and GOB3. The $\mathrm{O}_{2}$ concentration, monitored in a control core with an optode (3830, Aanderaa), did not decrease by more than $20 \%$ of the initial value during the incubation time. The incubation was terminated by uncapping each core and sampling its water phase with a syringe. An aliquot was transferred into a $12 \mathrm{~mL}$ Exetainer to which $100 \mu \mathrm{L}$ of a $37 \%$ formaldehyde solution was added. A second aliquot was filtered (PES, $0.45 \mu \mathrm{m}$ ), placed into a plastic vial, and immediately frozen for ${ }^{15} \mathrm{NH}_{4}^{+}$analysis. Subsequently, the water phase and upper $7-9 \mathrm{~cm}$ of sedi- 
ment were blended into slurry. Slurry samples were collected in $12 \mathrm{~mL}$ Exetainers to which $200 \mu \mathrm{L}$ of a $37 \%$ formaldehyde solution was added. The Exetainers were stored upside down in a fridge until later analysis of $\mathrm{N}_{2}$ isotopic compositions. An additional sample of the slurry was taken from each core, centrifuged (670 g for $10 \mathrm{~min}$ ), filtered (PES, $0.45 \mu \mathrm{m}$ ), placed into a plastic vial, and immediately frozen for ${ }^{15} \mathrm{NH}_{4}^{+}$ analysis.

\subsection{Anoxic slurry incubations}

Anoxic slurry incubations amended with ${ }^{15} \mathrm{NO}_{3}^{-}$and ${ }^{15} \mathrm{NH}_{4}^{+}$ were performed in order to estimate the contribution of anammox to total $\mathrm{N}_{2}$ production during the 2014 expedition (Risgaard-Petersen et al., 2003; Thamdrup and Dalsgaard, 2002). The experiment followed the procedure described in Bonaglia et al. (2014b). Briefly, the oxic layers were removed from two Gemini cores, and the $2 \mathrm{~cm}$ thick sediment layers below were extruded and homogenized in a glass bottle filled with helium $(\mathrm{He})$. One hundred milliliters of this sediment was transferred to a second glass bottle filled with $900 \mathrm{~mL}$ filtered (PES, $0.45 \mu \mathrm{m}$ ), anoxic bottom water. This slurry was bubbled with He for $10 \mathrm{~min}$ to remove any oxygen that entered during previous operations and was dispensed through Viton $^{\mathrm{TM}}$ tubing into a series of $12 \mathrm{~mL}$ Exetainers, each containing a $4 \mathrm{~mm}$ glass bead. The bottle was shaken vigorously while filling the Exetainers, maintaining the slurry homogeneous throughout dispensing. The Exetainers $(n=36)$ were filled completely and directly capped to avoid air bubbles. The samples were pre-incubated for up to $16 \mathrm{~h}$ on a rotating stirrer in order to remove any residual oxygen and nitrate. After pre-incubation, 15 Exetainers received $100 \mu \mathrm{L}$ of an anoxic $9 \mathrm{mM}^{15} \mathrm{NO}_{3}^{-}$solution (final ${ }^{15} \mathrm{NO}_{3}^{-}$concentration: $\sim 75 \mu \mathrm{M}) ; 15$ Exetainers received $100 \mu \mathrm{L}$ of an anoxic $9 \mathrm{mM}$ ${ }^{15} \mathrm{NH}_{4}^{+}+{ }^{14} \mathrm{NO}_{3}^{-}$solution (final ${ }^{15} \mathrm{NH}_{4}^{+}$and ${ }^{14} \mathrm{NO}_{3}^{-}$concentrations: $\sim 75 \mu \mathrm{M}$ each); and 6 Exetainers received no tracer and were used as a control. Triplicate vials from each treatment $(n=9)$ were sampled directly with a syringe by inserting a $3 \mathrm{~mL}$ He headspace. The subsample was centrifuged $(670 \mathrm{~g}$ for $10 \mathrm{~min})$, filtered (PES, $0.45 \mu \mathrm{m})$, placed into a plastic vial, and stored cold for later $\mathrm{NO}_{3}^{-}$and $\mathrm{NH}_{4}^{+}$analysis, from which the label percentage of the ${ }^{15} \mathrm{~N}$ compounds could be calculated. Formaldehyde $(200 \mu \mathrm{L}, 37 \%$ solution $)$ was injected into each of the He headspace Exetainers and mixed. The rest of the samples $(n=27)$ were incubated on the rotating stirrer for up to $8 \mathrm{~h}$ at station RA2 and up to $18 \mathrm{~h}$ at stations GOB1, GOB2, and GOB3. Triplicate vials from the ${ }^{15} \mathrm{~N}$ treatments were sacrificed at regular intervals during incubation by injecting $100 \mu \mathrm{L}$ of $37 \%$ formaldehyde. At the last time point, triplicate vials from the control treatment were also sacrificed to verify that no ${ }^{15} \mathrm{~N}$-tracer contamination had occurred. All Exetainers were stored upside down in a fridge until analysis of isotopic compositions of $\mathrm{N}_{2}$.

\subsection{Laboratory analyses and rate calculations}

Concentrations of TDN, $\mathrm{NH}_{4}^{+}, \mathrm{NO}_{3}^{-}$, and $\mathrm{NO}_{2}^{-}$were determined colorimetrically on a segmented flow nutrient analyzer system (OI Analytical, Flow Solution IV). The dissolved organic nitrogen (DON) concentration was calculated as the concentration of TDN minus the concentrations of $\mathrm{NH}_{4}^{+}$and $\mathrm{NO}_{x}^{-}$. Benthic fluxes from lander incubations were calculated as the net concentration change of solutes $\left(\mathrm{O}_{2}\right.$ and TDN) per area and time (Ståhl et al., 2004). The concentrations were corrected for the dilution that occurs when ambient bottom water enters the chamber as samples are withdrawn from the incubated chamber water. Benthic fluxes were calculated by multiplying the slope value of the regression of the concentration values versus time with the height of the incubated water column, which was estimated from the chamber volume. Fluxes were evaluated by the protocol described in Ekeroth et al. (2016) and considered to be significant if the $p$ value of the linear regression was $\leq 0.05$.

The isotopic composition of the $\mathrm{N}_{2}$ samples from the denitrification and anammox experiments was determined by headspace analysis using gas chromatography-isotope ratio mass spectrometry (GC-IRMS, DeltaV plus, Thermo) (De Brabandere et al., 2015). Slopes of the linear regression of ${ }^{29} \mathrm{~N}_{2}$ and ${ }^{30} \mathrm{~N}_{2}$ concentration against time were used to calculate production rates of labeled $\mathrm{N}_{2}\left(p^{29} \mathrm{~N}_{2}\right.$ and $p^{30} \mathrm{~N}_{2}$, respectively). Rates of $\mathrm{N}_{2}$ production in benthic lander incubations $\left(p_{14_{\text {lan }}}\right)$, and in the water column $\left(p_{14_{\mathrm{wc}}}\right)$ and slurried phase (= water + sediment $)\left(p_{14_{\text {sl }}}\right)$ of sediment core incubations, were calculated based on the revised isotope pairing technique (r-IPT) by Risgaard-Petersen et al. (2003). For clarity, $p_{14_{\text {lan }}}$ was calculated as

$p_{14_{\text {lan }}}=2 \times r_{14}\left(p^{29} \mathrm{~N}_{2 \text { lan }}+p^{30} \mathrm{~N}_{2_{\text {lan }}}\left(1-r_{14}\right)\right)$,

where $p^{29} \mathrm{~N}_{2 \text { lan }}$ and $p^{30} \mathrm{~N}_{2 \text { lan }}$ are the production rates of labeled $\mathrm{N}_{2}$ from the lander incubations and $r_{14}$ was calculated as

$r_{14}=\frac{(1-\mathrm{ra}) \times R_{29}-\mathrm{ra}}{(2-\mathrm{ra})}$,

where ra is the contribution of anammox to $\mathrm{N}_{2}$ production (see below) and $R_{29}$ is the ratio between $p^{29} \mathrm{~N}_{2 \text { lan }}$ and $p^{30} \mathrm{~N}_{2 \text { lan }}$. The parameters $p_{14_{\mathrm{wc}}}$ and $p_{14_{\mathrm{sl}}}$ were calculated likewise, and their equations are not presented here for conciseness.

As $p_{14_{\text {lan }}}$ takes into account only the $\mathrm{N}_{2}$ diffusing to the water column; the in situ or actual $\mathrm{N}_{2}$ production rate $\left(p_{14}\right)$ was calculated using the following formula:

$p_{14}=p_{14_{\text {lan }}} / F_{\mathrm{wc}}$,

where $F_{\mathrm{wc}}$ is the fraction of $\mathrm{N}_{2}$ production diffusing to the water column of sediment core incubations calculated as

$F_{\mathrm{wc}}=p_{14_{\mathrm{wc}}} / p_{14_{\mathrm{sl}}}$. 
The in situ $\mathrm{N}_{2}$ production rate was partitioned into $\mathrm{N}_{2}$ production coupled to nitrification $\left(p_{14_{\mathrm{n}}}\right)$ and $\mathrm{N}_{2}$ production depending on the water column nitrate $\left(p_{14_{\mathrm{w}}}\right)$ according to Risgaard-Petersen et al. (2003).

The contribution of anammox (ra) to the total $\mathrm{N}_{2}$ production - necessary to calculate $p_{14}$ (Risgaard-Petersen et al., 2003) - was estimated from anoxic slurry incubations. As significant rates of DNRA were measured in benthic lander incubations (see below), a correction to account for ${ }^{15} \mathrm{NH}_{4}^{+}$ production in Exetainers incubated with ${ }^{15} \mathrm{NO}_{3}^{-}$was performed based on Song et al. (2013). $F_{\mathrm{A}}$, the fraction of ${ }^{15} \mathrm{NH}_{4}^{+}$in the ammonium pool in the nitrate reduction zone, was estimated from the concentrations of ${ }^{15} \mathrm{NH}_{4}^{+}$and ${ }^{14} \mathrm{NH}_{4}^{+}$ at the final time point (10th syringe) from benthic lander incubations. $F_{\mathrm{A}}$ in these incubations was $\leq 0.06$. The in situ anammox rate (AAO) was calculated by multiplying $p_{14}$ by ra. The in situ denitrification rate (DEN) was calculated as the $p_{14}$ minus AAO.

Concentrations of labeled ammonium $\left({ }^{15} \mathrm{NH}_{4}^{+}\right)$were quantified after oxidation of $\mathrm{NH}_{4}^{+}$to $\mathrm{N}_{2}$ with hypobromite (Warembourg, 1993). Samples were purged with helium for $10 \mathrm{~min}$, treated with alkaline hypobromite, and analyzed by the headspace technique as described above. Slopes of the linear regression of ${ }^{15} \mathrm{NH}_{4}^{+}$concentration against time were used to calculate production rates of labeled ammonium $\left(p^{15} \mathrm{NH}_{4}^{+}\right)$after correction for adsorption assuming a dimensionless linear sorption coefficient of 1 (De Brabandere et al., 2015). DNRA rates in benthic lander incubations $\left(\right.$ DNRA $\left._{\text {lan }}\right)$ were calculated according to Christensen et al. (2000). Similar to $\mathrm{N}_{2}$ production rates, the in situ DNRA rate was calculated from the formula

$\mathrm{DNRA}=\mathrm{DNRA}_{\mathrm{lan}} / F_{\mathrm{wc}}$,

where $F_{\text {wc }}$ was used because $p^{15} \mathrm{NH}_{4}^{+}$was not detected in the time courses from sediment core incubations at GOB1-3 (see Results).

Sediment samples used for water content determination were dried at $70^{\circ} \mathrm{C}$ for $4-9$ days until reaching a constant weight. Porosity was calculated from the water content assuming a dry-sediment density of $2.65 \mathrm{~g} \mathrm{~mL}^{-1}$. The dried sediment was ground into a homogeneous powder and was analyzed for total $\mathrm{C}$ and total $\mathrm{N}$, as well as organic carbon $\left(\mathrm{C}_{\text {org }}\right)$ and organic nitrogen $\left(\mathrm{N}_{\text {org }}\right)$ after treatment with $\mathrm{HCl}$ fumes, with a Carlo Erba NA-1500 elemental analyzer modifying the procedure by Verardo et al. (1990). Only $\mathrm{C}_{\mathrm{org}}$ and $\mathrm{N}$ data are presented in this study. $\mathrm{N}_{\text {org }}$ data are not shown because of acidification artifacts.

Frozen sediment samples used for the analysis of ladderane lipids and the sediment accumulation rate (SAR) were weighed, freeze-dried, and weighed again. The freezedried sediment was manually homogenized into fine powder. Gamma-emitting radioisotopes for ${ }^{210} \mathrm{~Pb}$ dating were analyzed by gamma spectrometry following the protocol by Cutshall et al. (1983). For each sediment profile, the excess
${ }^{210} \mathrm{~Pb}$ activity concentration $\left(\mathrm{Bq} \mathrm{kg}^{-1}\right)$ was plotted versus the cumulative sediment mass $\left(\mathrm{g} \mathrm{cm}^{-2}\right)$ centered at the middle of each sediment layer. As bioturbation was absent (RA2), or low and restricted to the three top sediment centimeter (GOB1-3), an exponential regression curve of the form $e^{-k x}$ was fitted to the data, where $x$ is the cumulative sediment depth $\left(\mathrm{g} \mathrm{cm}^{-2}\right)$ and $k$ is a constant. Using the half-life of ${ }^{210} \mathrm{~Pb}$ (22.4 years), SAR $\left(\mathrm{g} \mathrm{cm}^{-2} \mathrm{yr}^{-1}\right)$ was determined from $(\ln (2) / 22.4) / k$. The $\mathrm{N}$ burial rate was calculated for each station by multiplying the SAR with the average sedimentary $\mathrm{N}$ content at the depth of $14-20 \mathrm{~cm}$, i.e., where it had reached a stable value.

For analysis of ladderane lipids, biomarkers for anammox bacteria, ground sediment was extracted using a modified method (additional extraction step using dichloromethane (DCM)) of Matyash et al. (2008). The target biomarker, a $\mathrm{C}_{20}$-[3]-ladderane monoether attached to a phosphocholine (PC) head group, was analyzed using high-performance liquid chromatography electrospray ionization tandem mass spectrometry (HPLC-ESI-MS/MS, Thermo). Separation was performed using reverse-phase chromatography on a Kinetex XB C18, $1.7 \mu \mathrm{m}, 100 \AA$ column (Phenomenex, USA) based on the methods of Lanekoff and Karlsson (2010) and Zhu et al. (2013). The PC-C 20 -[3]-ladderane monoether in the samples was quantified using a PC- $\mathrm{C}_{20}$-[3]-ladderane monoether standard, purified from anammox cell biomass from an anammox wastewater treatment reactor at Syvab, Himmerfjärdsverket, Grödinge, Sweden.

\subsection{Mass balance calculations and data analysis}

A benthic mass balance was calculated to assess whether the sediments were sources or sinks of $\mathrm{N}$ to/from the water column. It was calculated assuming steady-state conditions where $\mathrm{N}$ deposition on the sediment surface equals the sum of burial, $\mathrm{N}_{2}$ production, and the TDN efflux from the sediment. At each station, average rates of burial, $\mathrm{N}_{2}$ production, and TDN exchange were calculated for 2013 and 2014, and the average biannual values were summed to calculate $\mathrm{N}$ deposition. The relative contribution (\%) of each of the three processes was calculated by dividing each process by $\mathrm{N}$ deposition. Basin-wide annual $\mathrm{N}$ removal and recycling (in $\mathrm{kt} \mathrm{Nyr}^{-1}$ ) were calculated by scaling up the respective average rate to the GOB area reported in Sect. 2.1.

If not stated otherwise in the text, measurements are reported as average \pm standard error (SE). Detection limits of in situ rates were estimated as the median value of $2 \times \mathrm{SE}$ of the significant rates (De Brabandere et al., 2015) and were $3.4 \mu \mathrm{mol} \mathrm{N} \mathrm{m}{ }^{-2}$ day $^{-1}$ for DNRA and $29 \mu \mathrm{mol} \mathrm{N} \mathrm{m}^{-2}$ day $^{-1}$ for $p_{14}$. Statistical tests were performed in order to detect differences in solute fluxes and process rates between stations. Homogeneity of variance of the dataset was checked using Cochran's test, and one-way analysis of variance (ANOVA) test was performed. When the differences in the mean values among stations were greater than would be expected by 

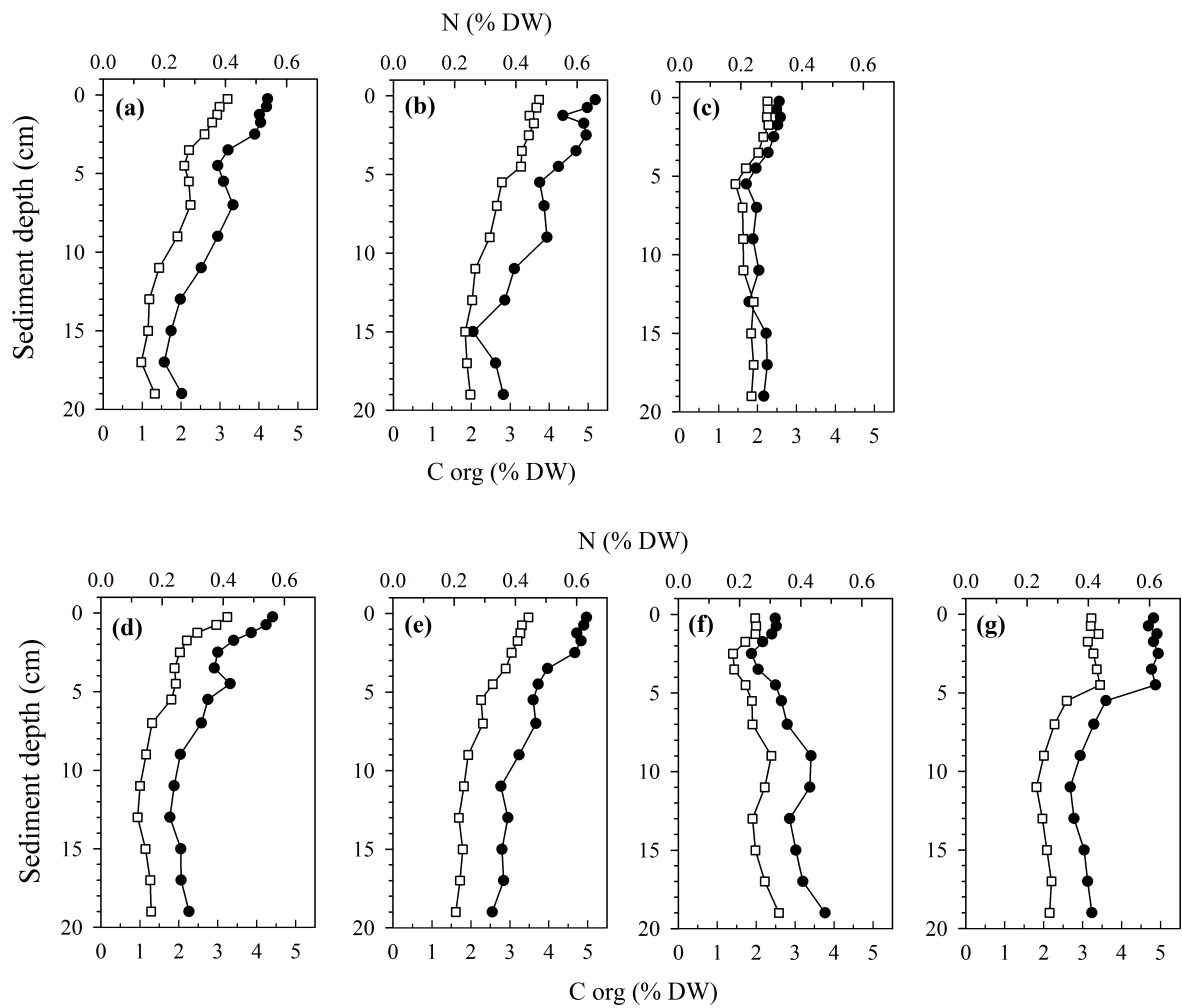

Figure 2. Profiles of organic carbon ( $\mathrm{C}_{\text {org }}$, represented by black dots) and nitrogen (N, represented by white squares) content in the sedimentary solid phase at station GOB1 (a), GOB2 (b), and GOB3 (c) in 2013, and GOB1 (d), GOB2 (e), GOB3 (f), and RA2 (g) in 2014. All values are expressed as $\mathrm{C}_{\text {org }}$ or $\mathrm{N}$ percentage of sediment dry weight (DW).

chance, pairwise multiple comparisons among stations were performed by the Tukey test. Correlations between process rates and environmental factors were tested using Pearson's correlation coefficient $(r)$. The level of significance was always set to $p<0.05$. Statistical analyses were performed with SigmaPlot 13.0 (Systat Software, CA, USA).

\section{Results}

\subsection{Sediment properties and macrofauna}

Sediment at GOB1 was dark olive brown in the top $3 \mathrm{~cm}$, where few burrows of the amphipod Monoporeia affinis were visible against the walls of the plastic liners. Sediment was light olive brown from 3 to $6 \mathrm{~cm}$ depth and characterized by brown/black laminations below $6 \mathrm{~cm}$ depth. Sediment at GOB2 was similar to GOB1 but with grey/black laminations instead. GOB3 sediment was light olive brown until $6 \mathrm{~cm}$ depth, followed by a grey clay layer. Both GOB2, and GOB3 sediments presented a sparse number of burrow structures of M. affinis down to $3 \mathrm{~cm}$ and faint burrow traces of the polychaete Marenzelleria spp. down to 6-7 cm depth. RA2 sediment was fluffy and olive brown colored in the top centimeter, followed by a black/dark olive brown layer. No burrows could be found at RA2. Relative abundances of macrofaunal taxa in the GOB sediments are presented in Fig. S1 in the Supplement.

Sediment porosities were highest at RA2, followed by GOB2, GOB1, and GOB3, and depth-integrated average porosities ranged from 0.82 to 0.93 at the four sampling sites (Fig. S2 in the Supplement). Sedimentary $\mathrm{C}_{\text {org }}$ and $\mathrm{N}$ generally decreased with sediment depth, except for GOB3 in 2014, where they increased slightly below $2.5 \mathrm{~cm}$ depth (Fig. 2). At RA2, both $\mathrm{C}_{\text {org }}$ and $\mathrm{N}$ were constant until $4.5 \mathrm{~cm}$, below which they started decreasing. The $\mathrm{C}_{\text {org }}$ and $\mathrm{N}$ content at the sediment surface (top $2 \mathrm{~cm}$ ) were 4-5 and 0.4$0.5 \%$ dry weight, respectively, except at GOB3, where they were $\sim 2.5$ and $\sim 0.25 \%$ dry weight. Sediment $\mathrm{C}_{\text {org }}: \mathrm{N}$ molar ratios increased slightly with depth at all stations except at RA2, where they were relatively constant (Fig. S3 in the Supplement). Sediment surface $\mathrm{C}_{\text {org }}$ : $\mathrm{N}$ ratios were $12-14$ at all stations except for GOB3, where they were lower (10-12).

Pore-water hydrogen sulfide $\left(\mathrm{H}_{2} \mathrm{~S}\right)$ concentrations were always below the detection limit $(0.3 \mu \mathrm{M})$ of the method. Porewater nitrite $\left(\mathrm{NO}_{2}^{-}\right)$concentrations were low at all stations $(<0.8 \mu \mathrm{M})$, while nitrate $\left(\mathrm{NO}_{3}^{-}\right)$or the nitrate-nitrite sum $\left(\mathrm{NO}_{x}^{-}\right)$showed a concentration peak $(6-18 \mu \mathrm{M})$ between the sediment surface and down to $1.25 \mathrm{~cm}$. $\mathrm{NH}_{4}^{+}$and DON concentrations in the pore water increased with sediment depth 
Table 2. Average rates of potential denitrification and anammox from anoxic slurry incubation expressed per gram of wet sediment with associated standard error (SE, $n=15$ ). Values of ra, and average abundances of PC-monoether ladderanes in the top $4 \mathrm{~cm}$ of sediment with associated SE $(n=4)$. DW is sediment dry weight, and WW is sediment wet weight.

\begin{tabular}{|c|c|c|c|c|c|c|c|c|c|c|}
\hline \multirow[t]{2}{*}{ Station } & \multirow[t]{2}{*}{$\begin{array}{l}\text { Sampling } \\
\text { season }\end{array}$} & \multicolumn{2}{|c|}{$\begin{array}{c}\text { Denitrification } \\
\left(\mathrm{nmol} \mathrm{N} \mathrm{g}-1 \mathrm{~h}^{-1}\right)\end{array}$} & \multicolumn{2}{|c|}{$\begin{array}{c}\text { Anammox } \\
\left(\mathrm{nmol} \mathrm{N} \mathrm{g}{ }^{-1} \mathrm{~h}^{-1}\right) \\
\end{array}$} & \multirow[t]{2}{*}{$\begin{array}{r}\mathrm{ra} \\
(\%)\end{array}$} & \multicolumn{2}{|c|}{$\begin{array}{l}\text { Ladderanes } \\
\left(\mathrm{pg} \mathrm{g}^{-1} \mathrm{DW}\right)\end{array}$} & \multicolumn{2}{|c|}{$\begin{array}{c}\text { Ladderanes } \\
\left(\mathrm{pg} \mathrm{g}^{-1} \mathrm{WW}\right) \\
\end{array}$} \\
\hline & & Average & SE & Average & SE & & Average & SE & Average & SE \\
\hline \multirow{2}{*}{ GOB1 } & June 2013 & & & & & & 1073 & 932 & 177 & 149 \\
\hline & July 2014 & 1.04 & 0.06 & 0.24 & 0.02 & 19 & 267 & 152 & 51 & 28 \\
\hline \multirow{2}{*}{ GOB2 } & June 2013 & & & & & & 264 & 148 & 33 & 17 \\
\hline & July 2014 & 1.86 & 0.07 & 0.59 & 0.02 & 26 & 34 & 14 & 6 & 2 \\
\hline \multirow{2}{*}{ GOB3 } & June 2013 & & & & & & 70 & 22 & 18 & 4 \\
\hline & July 2014 & 3.47 & 0.21 & 0.79 & 0.02 & 26 & 365 & 128 & 129 & 52 \\
\hline RA2 & July 2014 & 1.50 & 0.03 & 0.29 & 0.00 & 18 & 57 & 22 & 7 & 3 \\
\hline
\end{tabular}

at all stations (Fig. 3). Downcore $\mathrm{NH}_{4}^{+}$concentrations were highest at RA2, followed by GOB2 $\geq$ GOB1 $>$ GOB3. An $\mathrm{NH}_{4}^{+}$depleted surface layer $(<1.5 \mu \mathrm{M})$ was absent at $\mathrm{RA} 2$ but present and increasing in thickness from north to south at the GOB stations, ranging from $0.75 \mathrm{~cm}$ at GOB1 to 2.5 at GOB3. GOB2 had the highest DON concentrations, ranging from 406 to $677 \mu \mathrm{M}$ below $5.5 \mathrm{~cm}$ depth. DON was the dominant form of TDN in the pore water at all stations except for RA2, where $\mathrm{NH}_{4}^{+}$was the dominant species in the TDN pool.

The SARs at the four stations varied between 0.022 (GOB3) and $0.032 \mathrm{~g} \mathrm{~cm}^{-2} \mathrm{yr}^{-1}$ (GOB1) (Table 1). Burial rates of $\mathrm{N}$ ranged from 0.098 (GOB1) to $0.15 \mathrm{mmol} \mathrm{N} \mathrm{m}^{-2} \mathrm{day}^{-1}$ (RA2) (Table 1). The oxygen penetration depth (OPD) was higher in 2013 than in 2014 (Table 1). RA2 had lower OPD $(0.24 \mathrm{~cm})$ than the other three stations, where it ranged from 0.80 to $1.9 \mathrm{~cm}$ (Table 1).

The targeted ladderane lipid anammox biomarker (PC$\mathrm{C}_{20}$-[3]-ladderane monoether) could be detected at all stations at abundances that were highly variable, both spatially and temporally (Fig. 4). PC- $\mathrm{C}_{20}$-[3]-ladderane monoethers were more abundant in the top sediment layer and decreased with depth, with the exception of GOB2 in 2014, where a subsurface peak was recorded (Fig. 4). Higher abundances were present in 2013 than 2014 at GOB1 and GOB2, and the opposite was observed at GOB3. Average abundances in the top $4 \mathrm{~cm}$ of sediment were in the range $34-1073 \mathrm{pg} \mathrm{g}^{-1}$ sediment dry weight (DW) equivalent to 6-177 $\mathrm{pg} \mathrm{g}^{-1}$ sediment wet weight (WW) (Table 2). We could not find any significant correlation $(p>0.05)$ between ladderane abundances and environmental parameters (temperature, salinity, water depth, OPD).

\subsection{Benthic exchange of solutes and rates of $\mathbf{N}$ cycling processes}

Total oxygen uptake (TOU) varied between -5.0 (GOB2, 2013) and $-11.3 \mathrm{mmol} \mathrm{O}_{2} \mathrm{~m}^{-2} \mathrm{day}^{-1}$ (RA2, 2014) (Fig. 5a) and was significantly higher at RA2 than at the other stations (ANOVA, $p<0.001$ ). Separate fluxes of $\mathrm{NH}_{4}^{+}$and $\mathrm{NO}_{x}^{-}$were non-significant (data not shown) contrarily to the TDN fluxes, which were found to be significant and varied between $0.1 \mathrm{mmol} \mathrm{N} \mathrm{m}^{-2} \mathrm{day}^{-1}$ at GOB1 in 2014 and $0.9 \mathrm{mmol} \mathrm{N} \mathrm{m}^{-2}$ day $^{-1}$ at RA2 (Fig. 5b). The TDN efflux was mainly supported by DON because the contribution of DIN to the TDN flux was minor, and the pore-water concentrations just below the sediment surface were dominated by DON. TDN flux was non-significant at GOB3 in 2014. RA2 had a significantly higher TDN flux than GOB1 (2014) and GOB3 (ANOVA, Tukey pairwise test, $p<0.001$ ).

Sediment core incubations revealed that most of the ${ }^{15} \mathrm{~N}_{2}$ produced was retained in the sediment during incubation, with $F_{\mathrm{wc}}$ values of $0.26,0.23,0.33$, and 0.21 at GOB1, GOB2, GOB3, and RA2, respectively. Sediment core incubations were only carried out in 2014, but because sediment geometries and zonations were similar in the 2 years we expected consistent $F_{\mathrm{wc}}$. However, $F_{\mathrm{wc}}$ values in 2013 could have been slightly lower than those we measured in 2014 because OPDs were greater in 2013 than in 2014, implying that $\mathrm{N}_{2}$ production happened deeper down in the sediment. Thus, we cannot totally exclude underestimation of in situ $\mathrm{N}_{2}$ production rates in 2013.

Anoxic slurries incubated with ${ }^{15} \mathrm{NH}_{4}^{+}$and ${ }^{14} \mathrm{NO}_{3}^{-}$ revealed anammox activity in all the investigated sediments, with potential rates ranging from 0.2 to $0.8 \mathrm{nmol} \mathrm{N} \mathrm{g}^{-1} \mathrm{WW} \mathrm{h}^{-1}$ at GOB1 and GOB3, respectively (Table 2). Potential denitrification rates (from ${ }^{15} \mathrm{NO}_{3}^{-}$amended anoxic slurry incubations) were higher than anammox and varied from 1.0 to $3.5 \mathrm{nmol} \mathrm{N} \mathrm{g}^{-1} \mathrm{WW} \mathrm{h}^{-1}$ at GOB1 and GOB3, respectively (Table 2). Anammox 

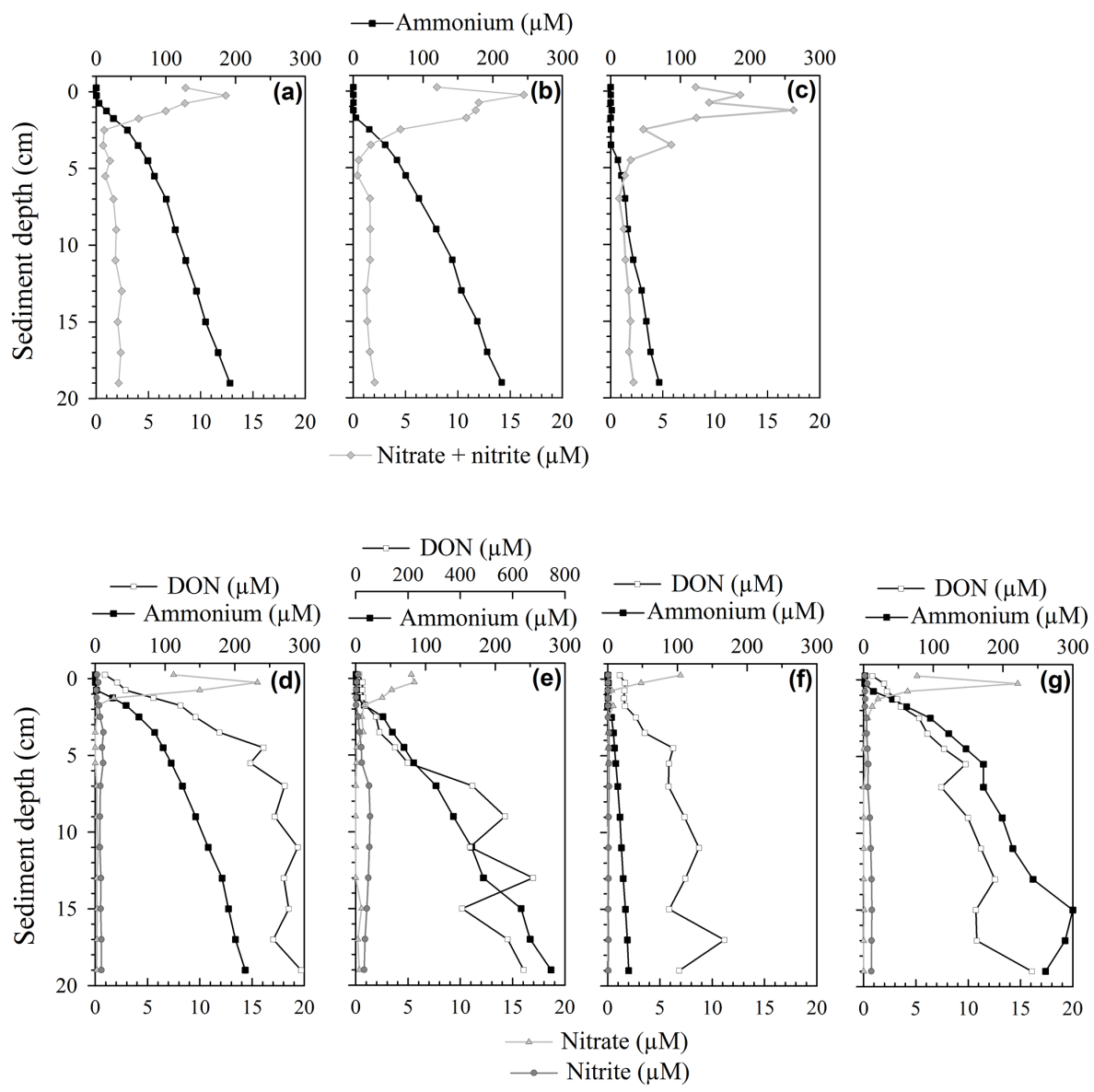

Figure 3. Pore-water concentration profiles of ammonium, nitrate, nitrite, and dissolved organic nitrogen (DON) as a function of depth in the sediment of GOB1 (a), GOB2 (b), and GOB3 (c) in 2013, and GOB1 (d), GOB2 (e), GOB3 (f), and RA2 (g) in 2014. Values on top of each profile represent bottom-water samples. Note a second $x$ axis with different scale for (e).
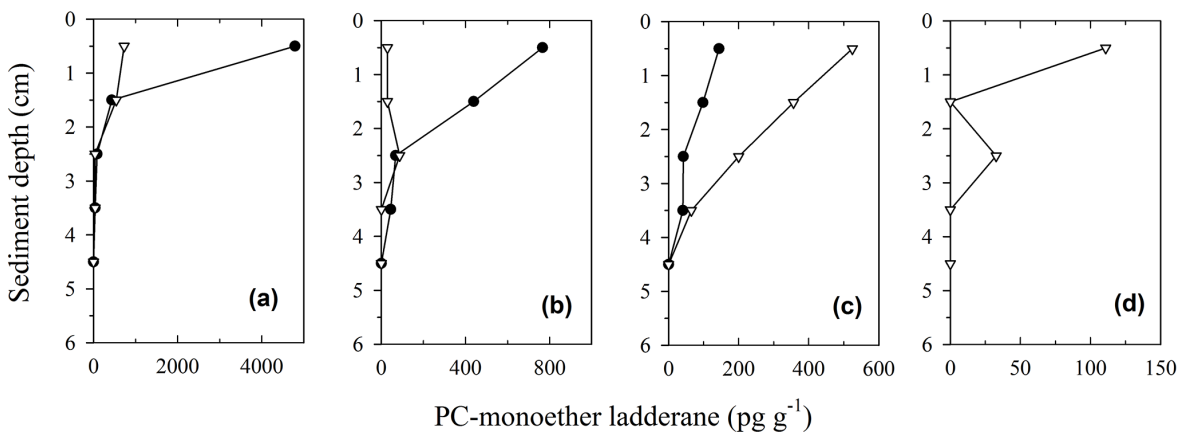

PC-monoether ladderane $\left(\mathrm{pg} \mathrm{g}^{-1}\right)$

Figure 4. Abundance profiles of $\mathrm{PC}-\mathrm{C}_{20}$-[3]-ladderane monoether ( $\mathrm{pg} \mathrm{g}^{-1}$ sediment dry weight) as a function of depth at GOB1 (a), GOB2 (b), GOB3 (c), and RA2 (d). Black dots represent values from 2013, while white triangles represent values from 2014. Please note different scales on the $x$ axes.

potential rates did not correlate either with average ladderane abundances $(r=0.62, p>0.05)$ or with ladderane abundances from the anoxic layer (1.5-3.5 depth) of the sediments $(r=0.70, p>0.05)$. Values of ra were $18 \%$ at RA2, $19 \%$ at GOB1 and GOB3, and $26 \%$ at GOB2, meaning that denitrification was more important than anammox at all stations (Table 2). There was no statistically significant difference (ANOVA, $p=0.167$ ) in ra between different stations.

Trends of in situ $\mathrm{N}_{2}$ production $(53-360 \mu \mathrm{molN}$ $\mathrm{m}^{-2}$ day $\left.^{-1}\right)$, denitrification $\left(43-297 \mu \mathrm{mol} \mathrm{N} \mathrm{m}{ }^{-2}\right.$ day $\left.^{-1}\right)$, and anammox $\left(10-63 \mu \mathrm{mol} \mathrm{N} \mathrm{m}{ }^{-2}\right.$ day $\left.^{-1}\right)$ were similar 

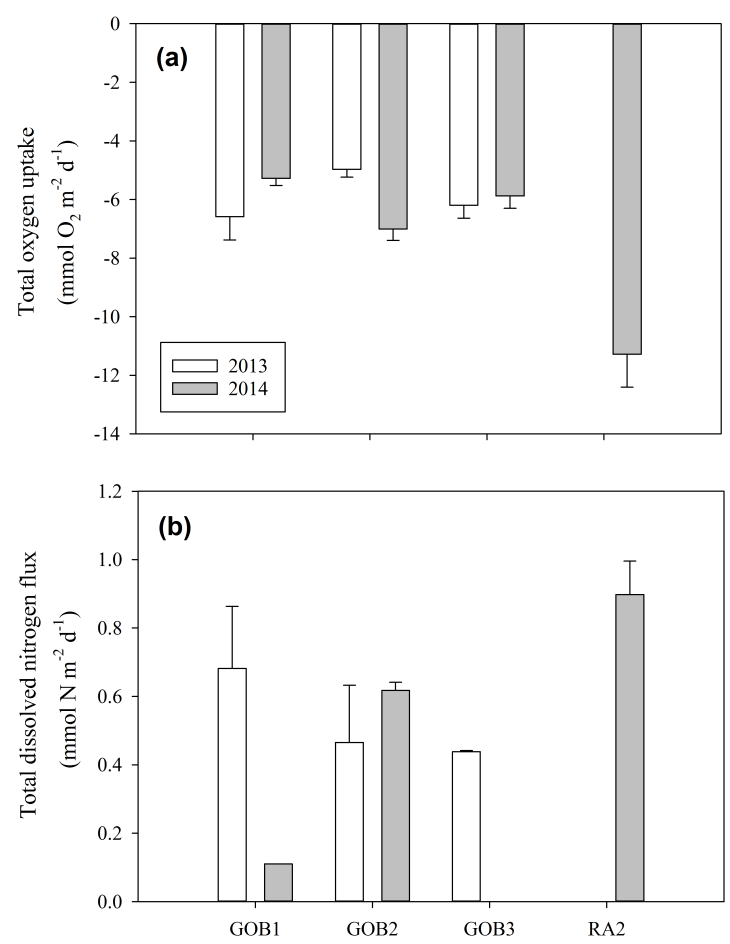

Figure 5. Total oxygen uptake (TOU) by the sediment (a) and flux of total dissolved nitrogen (TDN) across the sediment-water interface (b) measured at the four stations by in situ incubations with benthic chamber landers. Bars represent average value, and error bars represent standard errors. White bars and grey bars represent 2013 and 2014 rates, respectively. At station GOB3, TDN fluxes in 2014 were non-significant.

between stations, and rates were highest at RA2 and progressively lower at GOB2, GOB1, and GOB3 (Fig. 6a, $\mathrm{b}, \mathrm{c})$. $\mathrm{N}_{2}$ production was mainly sustained by $\mathrm{NO}_{3}^{-}$produced within the sediment by nitrification $\left(p_{14_{\mathrm{n}}}\right)$, which contributed $92,90,87$, and $83 \%$ at GOB2, GOB1, RA2, and GOB3, respectively (Fig. 6a). Thus, $\mathrm{N}_{2}$ production dependent on water column $\mathrm{NO}_{3}^{-}\left(p_{14_{\mathrm{w}}}\right)$ was minimal. Rates of total $\mathrm{N}_{2}$ production, $p_{14_{\mathrm{n}}}, p_{14_{\mathrm{w}}}$, and denitrification were significantly higher at RA2 (ANOVA, $p<0.01$ ) than at the other stations. Anammox rates at RA2 and GOB2-2014 were significantly higher than at GOB3 (ANOVA, Tukey pairwise test, $p<0.01)$.

At GOB1-3, DNRA could not be determined in sediment core incubations because $p^{15} \mathrm{NH}_{4}^{+}$was not detectable in the time courses, and this is consistent with the higher detection limits of core incubations compared to lander incubations. Thus, the in situ DNRA rates were calculated using $F_{\text {wc }}$ values from ${ }^{15} \mathrm{~N}_{2}$ accumulation in core incubations (see above), which may have caused an underestimation of the in situ DNRA rates because $\mathrm{NH}_{4}^{+}$diffusion to the water column is slower than $\mathrm{N}_{2}$ diffusion. DNRA was not detectable in situ at GOB3, which is consistent with low to undetectable efflux of TDN measured in benthic chambers without ${ }^{15} \mathrm{NO}_{3}^{-}$
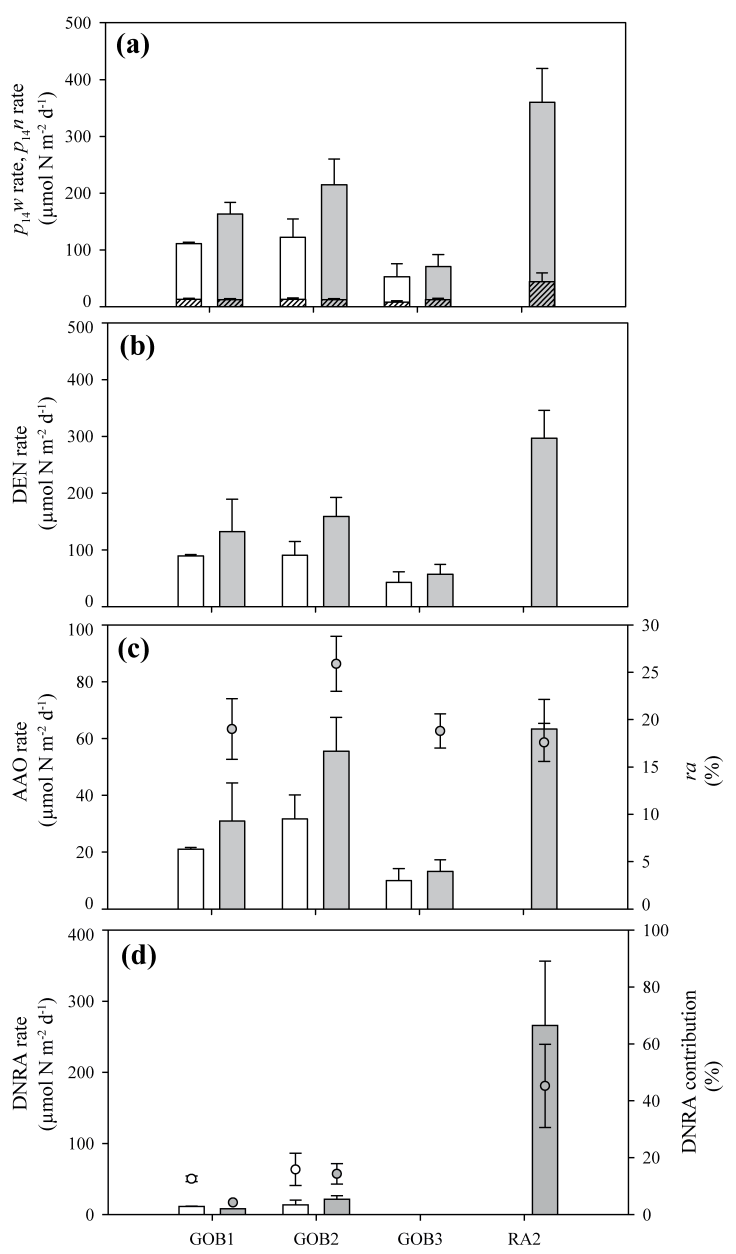

Figure 6. Average rates of $\mathrm{NO}_{x}^{-}$-reducing processes measured at the four stations by in situ incubations with benthic chamber landers amended with ${ }^{15} \mathrm{~N}$-nitrate, where white and grey bars represent 2013 and 2014 rates, respectively, with associated standard errors: (a) hatched bars represent rates of $\mathrm{N}_{2}$ production depending on the water column nitrate $\left(p_{14_{\mathrm{w}}}\right)$, while unhatched bars represent rates of $\mathrm{N}_{2}$ production coupled to nitrification $\left(p_{14_{n}}\right)$; (b) bars represent total denitrification (DEN) rates; (c) bars represent total anammox (AAO) rates and refer to the left $y$ axis, while grey dots represent percentages of ra and refer to the right $y$ axis; and (d) bars represent total DNRA rates and refer to the left $y$ axis. White and grey dots represent contribution of DNRA to total nitrate reduction (DEN rate + DNRA rate) and refer to the right $y$ axis for year 2013 and 2014, respectively. DNRA rates at GOB3 were not significant.

addition at this station (Figs. 5b, 6d). DNRA rates were lower than denitrification rates at GOB1 and GOB2 (ranging from 8 to $22 \mu \mathrm{mol} \mathrm{N} \mathrm{m}{ }^{-2}$ day $^{-1}$ ) (Fig. 6d). Station RA2 displayed DNRA rates which were comparable to the denitrification rates: $266 \pm 90$ and $297 \pm 49 \mu \mathrm{mol} \mathrm{N} \mathrm{m}^{-2}$ day $^{-1}$, respectively. RA2 had significantly higher DNRA rates than the other stations (ANOVA, $p<0.001$ ). 


\section{Discussion}

\subsection{Coexistence of multiple nitrate/nitrite reduction processes}

We measured rates of $\mathrm{N}_{2}$ production and DNRA by means of benthic chamber lander incubations, which give the most accurate results of benthic transformation processes (Glud and Blackburn, 2002; Tengberg et al., 1995), and by correcting these rates with the ra determined in parallel anoxic slurry incubations (Risgaard-Petersen et al., 2003). The in situ incubations indicated that denitrification, DNRA and anammox all contributed significantly to NRPs in the GOB sediments. To our knowledge, our study is the first that detects simultaneous activity of denitrification, DNRA, and anammox with in situ measurements. In anaerobic slurry incubations, the ${ }^{15} \mathrm{~N}$ IPT may be inaccurate when all three NRPs coexist because DNRA reduces ${ }^{15} \mathrm{NO}_{3}^{-}$to ${ }^{15} \mathrm{NH}_{4}^{+}$, which may affect the isotope distributions of anammox and denitrification. This is particularly significant when DNRA activity is high and the background concentration of ${ }^{14} \mathrm{NH}_{4}^{+}$is low (Song et al., 2016). At the stations where DNRA was detected, $F_{\mathrm{A}}$ (the fraction of ${ }^{15} \mathrm{NH}_{4}^{+}$in the ammonium pool) was $1.7 \%$ at GOB1 and GOB2, and 5.6\% at RA2, which would lead to a simultaneous $<5 \%$ overestimation of denitrification rate and underestimation of anammox rate (Song et al., 2016). Although this represents a small inaccuracy, we accounted for the influence of coupled DNRA-anammox during calculations. Rates reported are therefore representative for the in situ conditions.

Previous attempts to discern between the three NRPs in low-organic marine sediments involved the use of ex situ sediment core incubations (Crowe et al., 2012; Gihring et al., 2010). However, this method may not be representative of the in situ biogeochemical conditions when $\mathrm{N}$ cycling rates are low, e.g., at cold, low-productivity sites. In Arctic sediments, DNRA was indeed not detected $\left(<50 \mu \mathrm{mol} \mathrm{N} \mathrm{m}{ }^{-2}\right.$ day $\left.^{-1}\right)$ (Gihring et al., 2010). Benthic chamber incubations have 2.7- and 4.5-fold lower detection limits for denitrification and DNRA rate measurements than sediment core incubations, respectively (De Brabandere et al., 2015). This is due to core-to-core variation compared to repeated sampling of the same chamber. The in situ chamber has the advantage of covering a larger area than that covered by multiple coring. In addition, ex situ experiments generally involve heavy manipulation of the sediments, which can lead to alteration of sediment structures and infaunal biomass when small cores are used for sampling and incubation (Glud and Blackburn, 2002).

Rates of NRPs were dominated by denitrification (rate: 43-297 $\mu \mathrm{mol} \mathrm{N} \mathrm{m}{ }^{-2}$ day $^{-1}$; median: $91 \mu \mathrm{mol} \mathrm{N} \mathrm{m}^{-2}$ day $^{-1}$ ), which was in the lower range of rates previously measured in the GOB $\left(0-940 \mu \mathrm{mol} \mathrm{N} \mathrm{m}{ }^{-2}\right.$ day $^{-1}$; Stockenberg and Johnstone, 1997; Tuominen et al., 1998). However, those previous studies could not take into ac- count potential anammox activity and may not be representative of the in situ rate (Risgaard-Petersen et al., 2003). Denitrification rates from this study were in the lower range of rates found in the adjacent Baltic proper and Gulf of Finland $\left(38-1619 \mu \mathrm{mol} \mathrm{N} \mathrm{m}{ }^{-2}\right.$ day $^{-1}$; median: $170 \mu \mathrm{mol} \mathrm{N} \mathrm{m}{ }^{-2}$ day $^{-1}$; Bonaglia et al., 2014a; Deutsch et al., 2010; Hietanen and Kuparinen, 2008; Jäntti et al., 2011). However, our rates were comparable to those reported from Arctic and subarctic sediments $\left(33-340 \mu \mathrm{mol} \mathrm{N} \mathrm{m}^{-2}\right.$ day $^{-1}$; Gihring et al., 2010; Rysgaard et al., 2004; Seitzinger and Giblin, 1996). Anammox rates $\left(6-75 \mu \mathrm{mol} \mathrm{N} \mathrm{m}{ }^{-2}\right.$ day $^{-1}$; median: $27 \mu \mathrm{mol} \mathrm{N} \mathrm{m}{ }^{-2} \mathrm{day}^{-1}$ ) were higher than those measured in coastal areas of the Gulf of Finland and the central Baltic proper $\left(0-38 \mu \mathrm{mol} \mathrm{N} \mathrm{m}{ }^{-2}\right.$ day $^{-1}$; median: $11 \mu \mathrm{mol} \mathrm{N} \mathrm{m}{ }^{-2} \mathrm{day}^{-1}$; Bonaglia et al., 2014a; Hietanen and Kuparinen, 2008) but comparable to rates of Arctic sediments from Greenland and Svalbard (1$92 \mu \mathrm{mol} \mathrm{N} \mathrm{m}{ }^{-2}$ day $^{-1}$; Gihring et al., 2010; Rysgaard et al., 2004) and those of Celtic and Irish Sea sediments (2$46 \mu \mathrm{mol} \mathrm{N} \mathrm{m}{ }^{-2}$ day $^{-1}$; Jaeschke et al., 2009). It thus seems that the GOB sediments behave similarly to Arctic and subarctic sediments in terms of global $\mathrm{N}$ loss and partitioning between denitrification and anammox. Like Arctic sediments, denitrification might be limited by the availability of organic matter, which could increase the contribution of anammox to $\mathrm{N}$ loss compared to sediments from the central Baltic Sea.

DNRA rates found in this study (0$266 \mu \mathrm{mol} \mathrm{N} \mathrm{m}{ }^{-2}$ day $^{-1}$; median: $19 \mu \mathrm{mol} \mathrm{N} \mathrm{m}{ }^{-2}$ day $^{-1}$ ) were in the lower range of rates reported in previous studies from anthropogenically impacted Baltic Sea estuaries and hypoxic shelf sediments $\left(7-1060 \mu \mathrm{mol} \mathrm{N} \mathrm{m}{ }^{-2}\right.$ day $^{-1}$; median: $23 \mu \mathrm{mol} \mathrm{N} \mathrm{m}{ }^{-2}$ day $^{-1}$; Bonaglia et al., 2014a; Jäntti et al., 2011), although median values between these two environments were comparable. Interestingly, these comparisons suggest that the overall importance of DNRA in Baltic Sea sediments is similar across the gradient of trophic conditions. The only successful measurement of DNRA in Artic, subarctic, and boreal sediments to date describes rate of DNRA of only $0.12 \mu \mathrm{mol} \mathrm{N} \mathrm{m}^{-2} \mathrm{day}^{-1}$ in the lower St. Lawrence estuary (Crowe et al., 2012). Tropical and subtropical estuaries with high $\mathrm{C}_{\text {org }}$ and nitrate concentrations, however, have been shown to be dominated by DNRA at rates up to $27288 \mu \mathrm{mol} \mathrm{N} \mathrm{m}^{-2}$ day $^{-1}$ (An and Gardner, 2002; Dong et al., 2011). Temperate estuarine and coastal sediments investigated by the ${ }^{15} \mathrm{~N}$-labeling technique have in situ rates that are intermediate between those extreme values $\left(0-130 \mu \mathrm{mol} \mathrm{N} \mathrm{m}{ }^{-2} \mathrm{day}^{-1}\right.$; Christensen et al., 2000; Rysgaard et al., 1996) and are comparable to our range.

The presence of anammox bacteria was further substantiated by the quantification of ladderane lipids, specific biomarkers of anammox bacteria (Sinninghe Damsté et al., 2002). In our study we specifically targeted the intact PC-monoether ladderane as it represents a more accurate proxy for living anammox cells than core ladderane lipids 
(Boumann et al., 2006; Brandsma et al., 2011; Jaeschke et al., 2009). Ladderane abundances did not correlate with potential anammox rates. However, heterogeneity in microbial spatial distribution between the sediment used for the lipid analysis and the sediment used for the anammox incubations combined with the small sample size could affect this correlation. Our findings contrast with those of Bale et al. (2014), who observed a good agreement between intact PC-monoether ladderane abundance, potential anammox rates, 16S rRNA, and hszA gene copy abundance in North Sea sediment. However, other studies have also shown that the abundances of PC-monoether ladderane can be weak indicators of anammox activity (Jaeschke et al., 2009), possibly due to the fact that the PC-monoether ladderanes may be degradation lysis products of intact polar lipids (Brandsma et al., 2011). The abundance of PC-monoether ladderanes generally decreased with sediment depth, indicating that living anammox bacteria were mainly distributed close to the sediment surface, as previously reported for shallow sediments off northwest Africa and in the Irish Sea (Jaeschke et al., 2010, 2009). The range of abundance of PC-monoether ladderanes found in this study (34-1073 $\mathrm{pg} \mathrm{g}^{-1}$ ) was up to 2 orders of magnitude higher than that from Celtic and Irish Sea sediments (0-60 $\mathrm{pg} \mathrm{g}^{-1}$; Jaeschke et al., 2009), and that from northwest African sediments ( $<1-30 \mathrm{pg} \mathrm{g}^{-1}$; Jaeschke et al., 2010), but comparable to the range reported in organic-rich, muddy sediments from the North Sea (100-1250 $\mathrm{pg} \mathrm{g}^{-1}$; Lipsewers et al., 2014).

\subsection{Control factors of nitrate/nitrite reduction processes}

In marine sediments, denitrification and DNRA are mainly driven by the oxidation of organic $\mathrm{C}$ and hydrogen sulfide (Canfield et al., 2005). In the sediments of the Gulf of Bothnia we consider a major dependence of denitrifiers and DNRA bacteria on hydrogen sulfide unlikely as this compound never accumulated in the pore water at any of the investigated stations. It has recently been shown that reduced dissolved iron $\left(\mathrm{Fe}^{2+}\right)$ can serve as an electron donor for DNRA both in synthetic groundwater (Coby et al., 2011) and in seasonally hypoxic estuarine sediments (Robertson et al., 2016). In those sediments, DNRA was most active in sites with high pore-water $\mathrm{Fe}^{2+}$ concentrations $(>100 \mu \mathrm{M})$ in the top millimeter below the sediment surface (Robertson et al., 2016). We also consider this possibility unlikely for the sediments of the GOB as concentrations of pore-water $\mathrm{Fe}^{2+}$ in the top $2 \mathrm{~cm}$ of sediment were more than 1 order of magnitude lower than this, ranging from 3 to $12 \mu \mathrm{M}$ (Hannah S. Weber, unpublished data). In particular, RA2, the station with the highest rates of DNRA, had pore-water $\mathrm{Fe}^{2+}$ concentrations of only $5 \mu \mathrm{M}$ in the top sediment layer.

The absence of dissolved sulfide and low concentrations of $\mathrm{Fe}^{2+}$ in the GOB sediments rather indicate that the quantity and/or quality of organic matter exerted considerable in- fluence on denitrification and DNRA, and suggest that the apparent electron donor for nitrate reduction was organic $\mathrm{C}$ and not an inorganic substrate. Rates of heterotrophic nitrate respiration were generally low because of the oligotrophic nature of this ecosystem, which provides low organic $\mathrm{C}$ loading to the sediments. Nitrate respiration by denitrification and DNRA only accounted for $<1 \%$ of the total $\mathrm{C}$ mineralization inferred from the TOU at GOB3 and $\sim 2 \%$ at GOB 1 and GOB2, which is comparable to estuarine Baltic proper sediments, where rates were limited by labile $\mathrm{C}$ supply (Bonaglia et al., 2014a). At station RA2 nitrate respiration made up 5\% of the total $\mathrm{C}$ mineralization, and this higher percentage is consistent with the lower OPD at this station than at the other stations (Table 1). With similar $\mathrm{C}_{\text {org }}$ and $\mathrm{N}$ contents among stations, the relatively higher contribution of nitrate respiration at RA2 might be explained by process dependence on organic C quality rather than quantity, because at the offshore stations high remineralization rates in the water column render the sinking material more refractory (Algesten et al., 2004).

In continental shelf sediments with high reactive Mn content, it has been shown that denitrification is outcompeted by $\mathrm{Mn}$ reduction as $\mathrm{C}$ remineralization proceeds, which renders anammox relatively more important than denitrification (Thamdrup, 2012; Trimmer et al., 2013). In the Bothnian Bay there was a clear increase in surface sediment Mn content (dithionite-extractable) with water depth, at 47,66 , and $158 \mu \mathrm{mol} \mathrm{g}^{-1}$ DW at RA2, GOB1, and GOB2, respectively (Hannah S. Weber, unpublished data). However, ra and rates did not differ significantly between these three stations, indicating that the effect of Mn content on nitrate reduction in the GOB was much weaker than that reported from the deep Skagerrak, where denitrifiers were almost totally outcompeted by Mn reducers at Mn contents of $270-421 \mu \mathrm{mol} \mathrm{g}^{-1}$ (Trimmer et al., 2013). In benthic environments where phytoplanktonic organic matter sensu Redfield $(\mathrm{C}: \mathrm{N} \approx 6.6)$ is oxidized with nitrate as an electron acceptor through NRPs, the predicted ra is $29 \%$ (Thamdrup, 2012). However, $\mathrm{C}: \mathrm{N}$ ratios in the GOB were always higher than Redfield's ratio, which may explain the lower ra (18-26\%) to total $\mathrm{N}_{2}$ production that we found in the GOB sediments.

DNRA contribution to total nitrate reduction ranged from 7 to $63 \%$ in the subarctic oligotrophic Bothnian Bay. Because of the conservative method used to scale up the DNRA rates from the chamber incubations $\left(F_{\mathrm{wc}}\right.$ derived from the $p_{14}$ values and not from the $p^{15} \mathrm{NH}_{4}^{+}$; see Results), these DNRA contributions are likely underestimates. Yet, to our knowledge, our study is the first that demonstrates significant, even predominant (in one lander's chamber at RA2), DNRA rates in an oligotrophic environment. These results are in contrast with what has been proposed in the recent literature, i.e., that DNRA is negligible in oligotrophic systems of cold and well-oxygenated waters (Crowe et al., 2012; Gihring et al., 2010). DNRA was of major significance at the shallow, low-organic site, where the relatively high $\mathrm{C}: \mathrm{N}$ 
ratios of $\sim 14$ might provide a competitive advantage for DNRA bacteria vs. denitrifiers (Hardison et al., 2015; Kraft et al., 2014). Strains of the bacterium Shewanella spp., a genus that performs DNRA, were recently isolated in Arctic fjord sediments, and their highest optimal growth rate was at $18^{\circ} \mathrm{C}$, while denitrifiers had their optima at $0^{\circ} \mathrm{C}$ (Canion et al., 2013). We thus speculate that DNRA bacteria may have the capacity to increase their activity when the temperatures increased by $\sim 6^{\circ} \mathrm{C}$ from the winter to the summer, which was the case at RA2. It is clear from these results that further understanding of the controlling factors of heterotrophic DNRA in oligotrophic environments is necessary, and such studies should focus on kinetic experiments coupled to molecular analysis of DNRA bacteria.

\subsection{Fixed N loss vs. recycling in Gulf of Bothnia sediments}

We estimated the $\mathrm{N}$ mass balance for the benthic GOB environment assuming that $\mathrm{N}$ deposition on the sediment surface equals the sum of burial, $\mathrm{N}_{2}$ production, and total dissolved $\mathrm{N}$ efflux from the sediment (see Methods for calculations). The relative contribution of the $\mathrm{N}$ turnover mechanisms was comparable between the investigated stations (Fig. 7). Only $36-46 \%$ of the particulate organic N that sinks to the GOB sediments was permanently lost from the system. We estimated that bacterial $\mathrm{N}_{2}$ production and $\mathrm{N}$ burial together removed on average $160 \mathrm{kt} \mathrm{N} \mathrm{yr}^{-1}$ from the entire basin, which is 1.2-fold higher than the total external $\mathrm{N}$ load (Savchuk, 2005). The removal rate and the recycling rate were constrained by the low rates of $\mathrm{N}$ cycling processes at GOB3. The calculated flux of unsupported ${ }^{210} \mathrm{~Pb}$ was substantially lower at GOB3 (59 Bq m${ }^{-2} \mathrm{yr}^{-1}$ ) than at the other three stations $\left(121-230 \mathrm{~Bq} \mathrm{~m}^{-2} \mathrm{yr}^{-1}\right)$, which may indicate that this station temporally exhibited accumulation and erosion behavior. Unlike the other stations, there was no clear decrease of $\mathrm{C}_{\text {org }}$ or $\mathrm{N}$ content down-core at GOB3, and the $\mathrm{C}: \mathrm{N}$ ratios were relatively constant throughout the sediment profiles. Interestingly, in the 2014 profiles, both $\mathrm{C}_{\text {org }}$ and $\mathrm{N}$ content increased slightly with depth at this station. $\mathrm{C}: \mathrm{N}$ ratios generally increase when organic matter is decomposed due to preferential remineralization of $\mathrm{N}$ compared to $\mathrm{C}$ (Canfield et al., 2005), so these observations may suggest a decrease in organic matter degradation in the last few decades at this station.

The GOB sediments recycled 54-64\% of the deposited $\mathrm{N}$ to the water column in the form of TDN, which is close to the recycling percentage reported from anthropogenically impacted sediments, such as those in the shallow Yangtze estuary (Deng et al., 2015) and at the North Sea coast (Billen, 1978). Thus, it appears that in the summer the majority of the particulate organic $\mathrm{N}$ that sinks to the GOB sediments returns to the water column. Notably, the DON flux was the main component of the total flux of TDN in the GOB. High benthic export of DON to the water column may be a reason

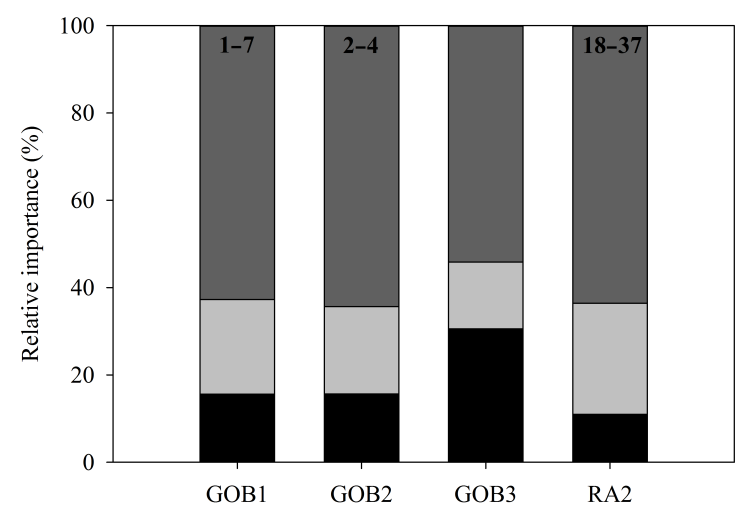

Figure 7. Relative importance in percentage of sediment burial (black bars), $\mathrm{N}_{2}$ production (light grey bars), and TDN efflux (dark grey bars) as $\mathrm{N}$ sink and source at the four stations. Range values represent the contribution (\%) of DNRA to the TDN efflux. Processes are expressed on a molar $(\mathrm{N})$ scale. See text for calculations.

for the high activity of bacterioplankton and the dominance of heterotrophy vs. autotrophy, which was found in the waters of the GOB (Algesten et al., 2004).

The calculated basin-wide recycling rate of $237 \mathrm{kt} \mathrm{N} \mathrm{yr}^{-1}$ was 1.8-fold higher than the terrestrial $\mathrm{N}$ load plus the $\mathrm{N}$ input from atmosphere (Savchuk, 2005). This high internal N recycling into the benthic-pelagic system of the GOB sustains water column primary production and may be a contributing factor to the strong P limitation of this basin (Rolff and Elfwing, 2015). In particular, DNRA in the shallow coastal sediment of the Bothnian Bay sustains up to $37 \%$ of the $\mathrm{N}$ recycled from the sediment to the water column, suggesting that this microbial process must be taken into account in $\mathrm{N}$ budgets not only in euxinic but also in oligotrophic systems. Although the assumption of steady state contains uncertainties as deposition and rates of $\mathrm{N}$ cycling may vary on a seasonal scale, our calculations give an indication of the relative importance of $\mathrm{N}$ loss vs. recycling in the GOB sediments during the period of maximal primary production (Klais et al., 2011).

\section{Data availability}

Further information and additional supporting data to this article can be found in the Supplement. All raw data are available upon request by email to the corresponding author.

The Supplement related to this article is available online at doi:10.5194/bg-14-285-2017-supplement. 
Acknowledgement. We acknowledge financial support from the Swedish Research Council, VR (grant no. 2012-3965 to Per O. J. Hall); Stockholm University's Baltic Ecosystem Adaptive Management, BEAM (funding to Stefano Bonaglia and Volker Brüchert); the Swedish Research Council for Environment, Agricultural Sciences and Spatial Planning, FORMAS (grant no. 215-2009-813 to Volker Brüchert); and a RA4 start-up grant from the Bolin Centre for Climate Research, Stockholm University (Jayne E. Rattray). We are grateful to the captains and crew of RV KBVO05 and RV Fyrbyggaren, and to Sarah Conrad and Susanne Bauer, for their assistance during work at sea. We thank the staff at the chemical laboratory at DEEP, Stockholm University, for assistance with nutrient analysis, and Sara Söhr at Syvab for the anammox biofilms.

Edited by: J. Middelburg

Reviewed by: two anonymous referees

\section{References}

Algesten, G., Wikner, J., Sobek, S., Tranvik, L. J., and Jansson, M.: Seasonal variation of $\mathrm{CO}_{2}$ saturation in the Gulf of Bothnia: Indications of marine net heterotrophy, Global Biogeochem. Cy., 18, GB4021, doi:10.1029/2004GB002232, 2004.

An, S. and Gardner, W. S.: Dissimilatory nitrate reduction to ammonium (DNRA) as a nitrogen link, versus denitrification as a sink in a shallow estuary (Laguna Madre/Baffin Bay, Texas), Mar. Ecol. Prog. Ser., 237, 41-50, doi:10.3354/meps237041, 2002.

Bale, N. J., Villanueva, L., Fan, H., Stal, L. J., Hopmans, E. C., Schouten, S., and Sinninghe Damsté, J. S.: Occurrence and activity of anammox bacteria in surface sediments of the southern North Sea, FEMS Microbiol. Ecol., 89, 99-110, doi:10.1111/1574-6941.12338, 2014.

Billen, G.: A budget of nitrogen recycling in North Sea sediments off the Belgian coast, Estuar. Coast. Mar. Sci., 7, 127-146, doi:10.1016/0302-3524(78)90070-1, 1978.

Billen, G., Silvestre, M., Grizzetti, B., Leip, A., Garnier, J., Voss, M., Howarth, R., Bouraoui, F., Lepisto, A., Kortelainen, P., Johnes, P., Curtis, C., Humborg, C., Smedberg, E., Kaste, Ø., Ganeshram, R. S., Beusen, A., and Lancelot, C.: Nitrogen flows from European watersheds to coastal marine waters, in: The European Nitrogen Assessment, Cambridge University Press, 2011.

Blackburn, T. H., Hall, P. O. J., Hulth, S., and Landén, A.: Organic-N loss by efflux and burial associated with a low efflux of inorganic $\mathrm{N}$ and with nitrate assimilation in Arctic sediments (Svalbard, Norway), Mar. Ecol. Prog. Ser., 141, 283-293, doi:10.3354/meps 141283, 1996.

Blomqvist, S., Ekeroth, N., Elmgren, R., and Hall, P. O. J.: Long overdue improvement of box corer sampling, Mar. Ecol. Prog. Ser., 538, 13-21, doi:10.3354/meps11405, 2015.

Bonaglia, S., Deutsch, B., Bartoli, M., Marchant, H. K., and Brüchert, V.: Seasonal oxygen, nitrogen and phosphorus benthic cycling along an impacted Baltic Sea estuary: regulation and spatial patterns, Biogeochemistry, 119, 139-160, doi:10.1007/s10533-014-9953-6, 2014a.

Bonaglia, S., Nascimento, F. J. A., Bartoli, M., Klawonn, I., and Brüchert, V.: Meiofauna increases bacterial deni- trification in marine sediments, Nat. Commun., 5, 5133, doi:10.1038/ncomms6133, 2014b.

Boumann, H. A., Hopmans, E. C., Van De Leemput, I., Op den Camp, H. J. M., Van De Vossenberg, J., Strous, M., Jetten, M. S. M., Sinninghe Damsté, J. S., and Schouten, S.: Ladderane phospholipids in anammox bacteria comprise phosphocholine and phosphoethanolamine headgroups, FEMS Microbiol. Lett., 258, 297-304, doi:10.1111/j.1574-6968.2006.00233.x, 2006.

Brandsma, J., van de Vossenberg, J., Risgaard-Petersen, N., Schmid, M. C., Engström, P., Eurenius, K., Hulth, S., Jaeschke, A., Abbas, B., Hopmans, E. C., Strous, M., Schouten, S., Jetten, M. S. M., and Damsté, J. S. S.: A multi-proxy study of anaerobic ammonium oxidation in marine sediments of the Gullmar Fjord, Sweden, Environ. Microbiol. Rep., 3, 360-366, doi:10.1111/j.17582229.2010.00233.x, 2011.

Brunnegård, J., Grandel, S., Ståhl, H., Tengberg, A., and Hall, P. O. J.: Nitrogen cycling in deep-sea sediments of the Porcupine Abyssal Plain, NE Atlantic, Prog. Oceanogr., 63, 159-181, doi:10.1016/j.pocean.2004.09.004, 2004.

Burgin, A. J. and Hamilton, S. K.: Have we overemphasized the role of denitrification in aquatic ecosystems? A review of nitrate removal pathways, Front. Ecol. Environ., 5, 89-96, doi:10.1890/1540-9295(2007)5[89:hwotro]2.0.co;2, 2007.

Canfield, D. E., Kristensen, E., and Thamdrup, B.: The nitrogen cycle, in: Aquatic Geomicrobiology, edited by: Canfield, D. E., Kristensen, E., and Thamdrup, B., Academic Press, 205-267, 2005.

Canion, A., Prakash, O., Green, S. J., Jahnke, L., Kuypers, M. M. M., and Kostka, J. E.: Isolation and physiological characterization of psychrophilic denitrifying bacteria from permanently cold Arctic fjord sediments (Svalbard, Norway), Environ. Microbiol., 15, 1606-1618, doi:10.1111/1462-2920.12110, 2013.

Christensen, P. B., Rysgaard, S., Sloth, N. P., Dalsgaard, T., and Schwærter, S.: Sediment mineralization, nutrient fluxes, denitrification and dissimilatory nitrate reduction to ammonium in an estuarine fjord with sea cage trout farms, Aquat. Microbiol. Ecol., 21, 73-84, doi:10.3354/ame021073, 2000.

Coby, A. J., Picardal, F., Shelobolina, E., Xu, H., and Roden, E. E.: Repeated Anaerobic Microbial Redox Cycling of Iron, Appl. Environ. Microbiol., 77, 6036-6042, doi:10.1128/aem.00276-11, 2011.

Crowe, S. A., Canfield, D. E., Mucci, A., Sundby, B., and Maranger, R.: Anammox, denitrification and fixed-nitrogen removal in sediments from the Lower St. Lawrence Estuary, Biogeosciences, 9, 4309-4321, doi:10.5194/bg-9-4309-2012, 2012.

Cutshall, N. H., Larsen, I. L., and Olsen, C. R.: Direct analysis of ${ }^{210} \mathrm{~Pb}$ in sediment samples: self-absorption corrections, Nucl. Instrum. Methods, 206, 309-312, doi:10.1016/01675087(83)91273-5, 1983.

De Brabandere, L., Bonaglia, S., Kononets, M., Viktorsson, L., Stigebrandt, A., Thamdrup, B., and Hall, P. O. J.: Oxygenation of an anoxic fjord basin strongly stimulates benthic denitrification and DNRA, Biogeochemistry, 126, 131-152, doi:10.1007/s10533-015-0148-6, 2015.

Deng, F., Hou, L., Liu, M., Zheng, Y., Yin, G., Li, X., Lin, X., Chen, F., Gao, J., and Jiang, X.: Dissimilatory nitrate reduction processes and associated contribution to nitrogen removal in sediments of the Yangtze Estuary, J. Geophys. Res.-Biogeo., 120, 1521-1531, doi:10.1002/2015JG003007, 2015. 
Deutsch, B., Forster, S., Wilhelm, M., Dippner, J. W., and Voss, M.: Denitrification in sediments as a major nitrogen sink in the Baltic Sea: an extrapolation using sediment characteristics, Biogeosciences, 7, 3259-3271, doi:10.5194/bg-7-3259-2010, 2010.

Dong, L. F., Sobey, M. N., Smith, C. J., Rusmana, I., Phillips, W., Stott, A., Osborn, A. M., and Nedwell, D. B.: Dissimilatory reduction of nitrate to ammonium, not denitrification or anammox, dominates benthic nitrate reduction in tropical estuaries, Limnol. Oceanogr., 56, 279-291, doi:10.4319/lo.2011.56.1.0279, 2011.

Ekeroth, N., Kononets, M., Walve, J., Blomqvist, S., and Hall, P. O. J.: Effects of oxygen on recycling of biogenic elements from sediments of a stratified coastal Baltic Sea basin, J. Mar. Syst., 154, 206-219, doi:10.1016/j.jmarsys.2015.10.005, 2016.

Elmgren, R.: Understanding human impact on the Baltic ecosystem: Changing views in recent decades, Ambio, 30, 222-231, doi:10.1579/0044-7447-30.4.222, 2001.

Engström, P., Dalsgaard, T., Hulth, S., and Aller, R. C.: Anaerobic ammonium oxidation by nitrite (anammox): Implications for $\mathrm{N}_{2}$ production in coastal marine sediments, Geochim. Cosmochim. Ac., 69, 2057-2065, doi:10.1016/j.gca.2004.09.032, 2005.

Gihring, T. M., Lavik, G., Kuypers, M. M. M., and Kostka, J. E.: Direct determination of nitrogen cycling rates and pathways in Arctic fjord sediments (Svalbard, Norway), Limnol. Oceanogr., 55, 740-752, doi:10.4319/lo.2009.55.2.0740, 2010.

Glud, R. N. and Blackburn, N.: The effects of chamber size on benthic oxygen uptake measurements: A simulation study, Ophelia, 56, 23-31, doi:10.1080/00785236.2002.10409486, 2002.

Håkansson, B., Alenius, P., and Brydsten, L.: Physical environment in the Gulf of Bothnia, Ambio, 8, 5-12, 1996.

Hardison, A. K., Algar, C. K., Giblin, A. E., and Rich, J. J.: Influence of organic carbon and nitrate loading on partitioning between dissimilatory nitrate reduction to ammonium (DNRA) and $\mathrm{N}_{2}$ production, Geochim. Cosmochim. Ac., 164, 146-160, doi:10.1016/j.gca.2015.04.049, 2015.

Hietanen, S. and Kuparinen, J.: Seasonal and short-term variation in denitrification and anammox at a coastal station on the Gulf of Finland, Baltic Sea, Hydrobiologia, 596, 67-77, doi:10.1007/s10750-007-9058-5, 2008.

Howarth, R. W. and Marino, R.: Nitrogen as the limiting nutrient for eutrophication in coastal marine ecosystems: Evolving views over three decades, Limnol. Oceanogr., 51, 364-376, doi:10.4319/lo.2006.51.1_part_2.0364, 2006.

Jaeschke, A., Rooks, C., Trimmer, M., Nicholls, J. C., Hopmans, E. C., Schouten, S., and Sinninghe Damsté, J. S.: Comparison of ladderane phospholipid and core lipids as indicators for anaerobic ammonium oxidation (anammox) in marine sediments, Geochim. Cosmochim. Ac., 73, 2077-2088, doi:10.1016/j.gca.2009.01.013, 2009.

Jaeschke, A., Abbas, B., Zabel, M., Hopmans, E. C., Schouten, S., and Sinninghe Damsté, J. S.: Molecular evidence for anaerobic ammonium-oxidizing (anammox) bacteria in continental shelf and slope sediments off northwest Africa, Limnol. Oceanogr., 55, 365-376, doi:10.4319/10.2010.55.1.0365, 2010.

Jäntti, H., Stange, F., Leskinen, E., and Hietanen, S.: Seasonal variation in nitrification and nitrate-reduction pathways in coastal sediments in the Gulf of Finland, Baltic Sea, Aquat. Microbiol. Ecol., 63, 171-181, doi:10.3354/ame01492, 2011.
Jørgensen, B. B. and Nelson, D. C.: Sulfide oxidation in marine sediments: Geochemistry meets microbiology, Geol. Soc. Am. Special Papers, 379, 63-81, doi:10.1130/0-8137-2379-5.63, 2004.

Klais, R., Tamminen, T., Kremp, A., Spilling, K., and Olli, K.: Decadal-Scale Changes of Dinoflagellates and Diatoms in the Anomalous Baltic Sea Spring Bloom, PLoS ONE, 6, e21567, doi:10.1371/journal.pone.0021567, 2011.

Kraft, B., Tegetmeyer, H. E., Sharma, R., Klotz, M. G., Ferdelman, T. G., Hettich, R. L., Geelhoed, J. S., and Strous, M.: The environmental controls that govern the end product of bacterial nitrate respiration, Science, 345, 676-679, doi:10.1126/science.1254070, 2014.

Lanekoff, I. and Karlsson, R.: Analysis of intact ladderane phospholipids, originating from viable anammox bacteria, using RP-LC-ESI-MS, Anal. Bioanal. Chem., 397, 3543-3551, doi:10.1007/s00216-010-3913-3, 2010.

Leppäranta, M. and Myrberg, K.: Topography and hydrography of the Baltic Sea, in: Physical Oceanography of the Baltic Sea, Springer Praxis Books, Springer Berlin Heidelberg, 41-88, 2009.

Lipsewers, Y. A., Bale, N. J., Hopmans, E. C., Schouten, S., Damsté, J. S. S., and Villanueva, L.: Seasonality and depth distribution of the abundance and activity of ammonia oxidizing microorganisms in marine coastal sediments (North Sea), Front Microbiol., 5, 472, doi:10.3389/fmicb.2014.00472, 2014.

Matyash, V., Liebisch, G., Kurzchalia, T. V., Shevchenko, A., and Schwudke, D.: Lipid extraction by methyl-tert-butyl ether for high-throughput lipidomics, J. Lipid Res., 49, 1137-1146, doi:10.1194/jlr.D700041-JLR200, 2008.

Nielsen, L. P.: Denitrification in sediment determined from nitrogen isotope pairing, FEMS Microbiol. Ecol., 86, 357-362, doi:10.1111/j.1574-6968.1992.tb04828.x, 1992.

Pettersson, C., Allard, B., and Borén, H.: River discharge of humic substances and humic-bound metals to the Gulf of Bothnia, Estuar. Coast. Shelf S., 44, 533-541, doi:10.1006/ecss.1996.0159, 1997.

Risgaard-Petersen, N., Nielsen, L. P., Rysgaard, S., Dalsgaard, T., and Meyer, R. L.: Application of the isotope pairing technique in sediments where anammox and denitrification coexist, Limnol. Oceanogr.-Meth., 1, 63-73, doi:10.4319/lom.2003.1.63, 2003.

Robertson, E. K., Roberts, K. L., Burdorf, L. D. W., Cook, P., and Thamdrup, B.: Dissimilatory nitrate reduction to ammonium coupled to $\mathrm{Fe}(\mathrm{II})$ oxidation in sediments of a periodically hypoxic estuary, Limnol. Oceanogr., 61, 365-381, doi:10.1002/lno.10220, 2016.

Rolff, C. and Elfwing, T.: Increasing nitrogen limitation in the Bothnian Sea, potentially caused by inflow of phosphaterich water from the Baltic Proper, Ambio, 44, 601-611, doi:10.1007/s13280-015-0675-3, 2015.

Rysgaard, S., Risgaard-Petersen, N., and Sloth, N. P.: Nitrification, denitrification, and nitrate ammonification in sediments of two coastal lagoons in Southern France, Hydrobiologia, 329, 133141, doi:10.1007/bf00034553, 1996.

Rysgaard, S., Glud, R. N., Risgaard-Petersen, N., and Dalsgaard, T.: Denitrification and anammox activity in arctic marine sediments, Limnol. Oceanogr., 49, 1493-1502, 2004.

Savchuk, O. P.: Resolving the Baltic Sea into seven subbasins: $\mathrm{N}$ and P budgets for 1991-1999, J. Mar. Syst., 56, 1-15, doi:10.1016/j.jmarsys.2004.08.005, 2005. 
Savchuk, O. P.: Large-Scale Dynamics of Hypoxia in the Baltic Sea, in: Chemical Structure of Pelagic Redox Interfaces, edited by: Yakushev, E. V., The Handbook of Environmental Chemistry, Springer Berlin Heidelberg, 137-160, 2013.

Seitzinger, S., Harrison, J. A., Bohlke, J. K., Bouwman, A. F., Lowrance, R., Peterson, B., Tobias, C., and Van Drecht, G.: Denitrification across landscapes and waterscapes: A synthesis, Ecol. Appl., 16, 2064-2090, doi:10.1890/10510761(2006)016[2064:dalawa]2.0.co;2, 2006.

Seitzinger, S. P. and Giblin, A. E.: Estimating denitrification in North Atlantic continental shelf sediments, Biogeochemistry, 35, 235-260, doi:10.1007/bf02179829, 1996.

Sinninghe Damsté, J. S., Strous, M., Rijpstra, W. I. C., Hopmans, E. C., Geenevasen, J. A. J., van Duin, A. C. T., van Niftrik, L. A., and Jetten, M. S. M.: Linearly concatenated cyclobutane lipids form a dense bacterial membrane, Nature, 419, 708-712, doi:10.1038/nature01128, 2002.

Song, G. D., Liu, S. M., Marchant, H., Kuypers, M. M. M., and Lavik, G.: Anammox, denitrification and dissimilatory nitrate reduction to ammonium in the East China Sea sediment, Biogeosciences, 10, 6851-6864, doi:10.5194/bg-10-6851-2013, 2013.

Song, G. D., Liu, S. M., Kuypers, M. M. M., and Lavik, G.: Application of the isotope pairing technique in sediments where anammox, denitrification, and dissimilatory nitrate reduction to ammonium coexist, Limnol. Oceanogr.-Meth., 14, 801-815, doi:10.1002/lom3.10127, 2016.

Ståhl, H., Tengberg, A., Brunnegård, J., and Hall, P. O. J.: Recycling and burial of organic carbon in sediments of the Porcupine Abyssal Plain, NE Atlantic, Deep-Sea Res. Pt. I, 51, 777-791, doi:10.1016/j.dsr.2004.02.007, 2004.

Stockenberg, A. and Johnstone, R. W.: Benthic denitrification in the Gulf of Bothnia, Estuar. Coast. Shelf S., 45, 835-843, doi:10.1006/ecss.1997.0271, 1997.

Tamminen, T. and Andersen, T.: Seasonal phytoplankton nutrient limitation patterns as revealed by bioassays over Baltic Sea gradients of salinity and eutrophication, Mar. Ecol. Prog. Ser., 340, 121-138, doi:10.3354/meps340121, 2007.

Tengberg, A., De Bovee, F., Hall, P. O. J., Berelson, W., Chadwick, D., Ciceri, G., Crassous, P., Devol, A., Emerson, S., Gage, J., Glud, R., Graziottini, F., Gundersen, J., Hammond, D., Helder, W., Hinga, K., Holby, O., Jahnke, R., Khripounoff, A., Lieberman, S., Nuppenau, V., Pfannkuche, O., Reimers, C., Rowe, G., Sahami, A., Sayles, F., Schurter, M., Smallman, D., Wehrli, B., and De Wilde, P.: Benthic chamber and profiling landers in oceanography - A review of design, technical solutions and functioning, Prog. Oceanogr., 35, 253-294, doi:10.1016/00796611(95)00009-6, 1995.
Tengberg, A., Stahl, H., Gust, G., Müller, V., Arning, U., Andersson, H., and Hall, P. O. J.: Intercalibration of benthic flux chambers I. Accuracy of flux measurements and influence of chamber hydrodynamics, Prog. Oceanogr., 60, 1-28, doi:10.1016/j.pocean.2003.12.001, 2004.

Thamdrup, B.: New pathways and processes in the global nitrogen cycle, Annu. Rev. Ecol. Evol. S., 43, 407-428, doi:10.1146/annurev-ecolsys-102710-145048, 2012.

Thamdrup, B. and Dalsgaard, T.: Production of $\mathrm{N}_{2}$ through anaerobic ammonium oxidation coupled to nitrate reduction in marine sediments, Appl. Environ. Microbiol., 68, 1312-1318, doi:10.1128/aem.68.3.1312-1318.2002, 2002.

Trimmer, M., Engström, P., and Thamdrup, B.: Stark contrast in denitrification and anammox across the deep Norwegian trench in the Skagerrak, Appl. Environ. Microbiol., 79, 7381-7389, doi:10.1128/AEM.01970-13, 2013.

Tuominen, L., Heinanen, A., Kuparinen, J., and Nielsen, L. P.: Spatial and temporal variability of denitrification in the sediments of the northern Baltic Proper, Mar. Ecol. Prog. Ser., 172, 13-24, doi:10.3354/meps172013, 1998.

Vaquer-Sunyer, R. and Duarte, C. M.: Thresholds of hypoxia for marine biodiversity, P. Natl. Acad. Sci. USA, 105, 15452-15457, doi:10.1073/pnas.0803833105, 2008.

Verardo, D. J., Froelich, P. N., and McIntyre, A.: Determination of organic carbon and nitrogen in marine sediments using the Carlo Erba NA-1500 analyzer, Deep-Sea Res. Pt. I, 37, 157-165, doi:10.1016/0198-0149(90)90034-S, 1990.

Warembourg, F. R.: Nitrogen fixation in soil and plant systems, in: Nitrogen isotope techniques, edited by: Knowles, R. and Blackburn, T. H., Academic Press San Diego, USA, 127-156, 1993.

Zhu, C., Lipp, J. S., Wörmer, L., Becker, K. W., Schröder, J., and Hinrichs, K.-U.: Comprehensive glycerol ether lipid fingerprints through a novel reversed phase liquid chromatographymass spectrometry protocol, Org. Geochem., 65, 53-62, doi:10.1016/j.orggeochem.2013.09.012, 2013. 